Prepared in cooperation with the lowa Department of Natural Resources

\title{
Simulation of Daily Streamflow for Nine River Basins in Eastern lowa Using the Precipitation-Runoff Modeling System
}

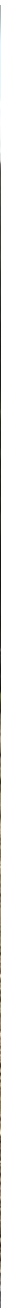

Scientific Investigations Report 2015-5129

U.S. Department of the Interior

U.S. Geological Survey 
Cover. Turkey River at Elkader, lowa, 2014 (front cover); Maquoketa River near Green Island, lowa, 2015 (upper, back cover); and Wapsipinicon River at Oxford Mills, lowa, 2014 (lower, back cover). Photographs by U.S. Geological Survey, lowa Water Science Center. 


\section{Simulation of Daily Streamflow for Nine River Basins in Eastern lowa Using the Precipitation-Runoff Modeling System}

By Adel E. Haj, Daniel E. Christiansen, and Kasey J. Hutchinson

Prepared in cooperation with the lowa Department of Natural Resources

Scientific Investigations Report 2015-5129 


\title{
U.S. Department of the Interior SALLY JEWELL, Secretary
}

\section{U.S. Geological Survey \\ Suzette M. Kimball, Acting Director}

\author{
U.S. Geological Survey, Reston, Virginia: 2015
}

For more information on the USGS - the Federal source for science about the Earth, its natural and living resources, natural hazards, and the environment—visit http://www.usgs.gov or call 1-888-ASK-USGS.

For an overview of USGS information products, including maps, imagery, and publications, visit http://www.usgs.gov/pubprod/.

Any use of trade, firm, or product names is for descriptive purposes only and does not imply endorsement by the U.S. Government.

Although this information product, for the most part, is in the public domain, it also may contain copyrighted materials as noted in the text. Permission to reproduce copyrighted items must be secured from the copyright owner.

Suggested citation:

Haj, A.E., Christiansen, D.E., and Hutchinson, K.J., 2015, Simulation of daily streamflow for nine river basins in eastern lowa using the Precipitation-Runoff Modeling System: U.S. Geological Survey Scientific Investigations Report 2015-5129, 29 p., http://dx.doi.org/10.3133/sir20155129.

ISSN 2328-0328 (online) 


\section{Contents}

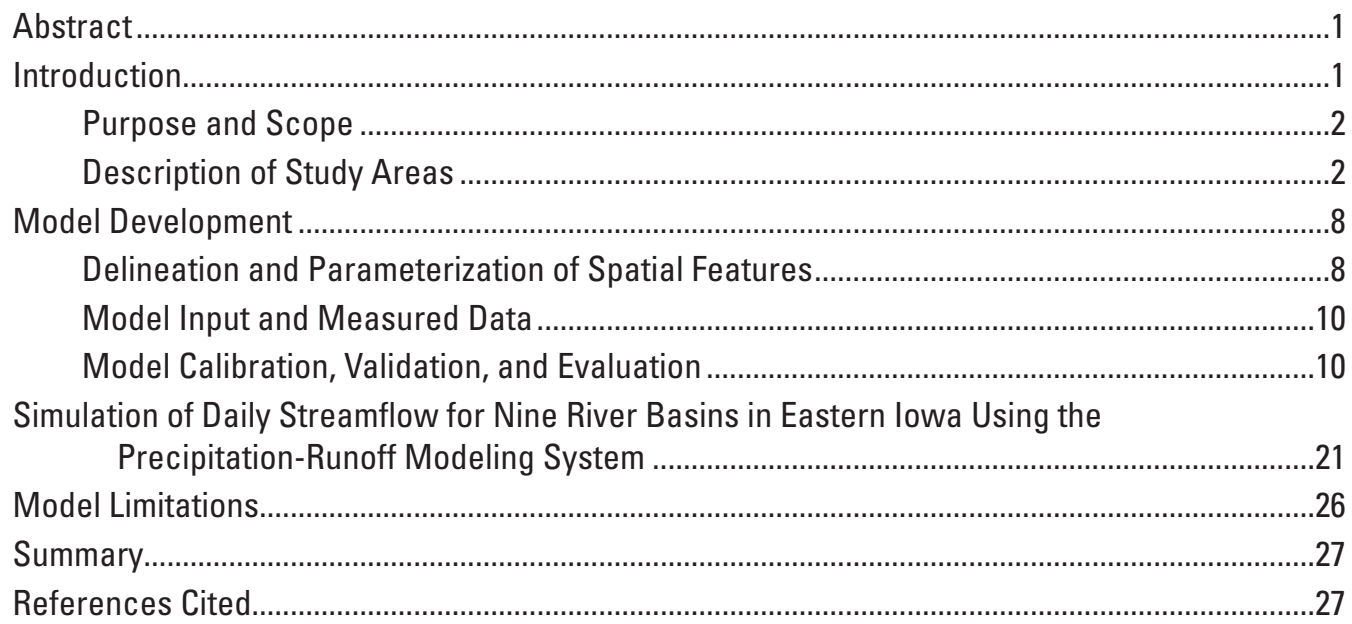

\section{Figures}

1. Map showing landform regions for Precipitation-Runoff Modeling System models of nine river basins in eastern lowa.

2. Map showing simulated stream segments and U.S. Geological Survey streamflow-gaging stations providing measured data for Precipitation-Runoff Modeling System models of nine river basins in eastern lowa.

3. Schematic diagram of a basin and its meteorological inputs simulated by the Precipitation-Runoff Modeling System

4. Map showing National Oceanic and Atmospheric Administration's National Weather Service Cooperative Observer Program meteorological stations and hydrologic response units used in the Precipitation-Runoff Modeling System models or nine river basins in eastern lowa.

5. Graphs showing a comparison of measured and simulated flow at selected U.S. Geological Survey streamflow-gaging stations used in calibrating Precipitation-Runoff Modeling System models of nine river basins in eastern lowa, water years 2002-12. 


\section{Tables}

1. U.S. Geological Survey streamflow-gaging stations used for input, calibrating, and validating the Precipitation-Runoff Modeling System models of nine river basins in eastern lowa.

2. National Oceanic and Atmospheric Administration's National Weather Service Cooperative Observer Program meteorological stations used in the Precipitation-Runoff Modeling System models of nine river basins in eastern lowa

3. Nash-Sutcliffe efficiency, coefficient of determination, percent bias, and root mean square error-observation standard deviation ratio statistic values at U.S. Geological Survey streamflow-gaging stations used for calibration or validation periods in the Precipitation-Runoff Modeling System models of nine river basins in eastern lowa

4. Calibrated parameters and Let Us Calibrate calibration steps for the Precipitation-Runoff Modeling System models of nine river basins in eastern lowa

\section{Conversion Factors}

Inch/Pound to International System of Units

\begin{tabular}{lcl}
\hline & Multiply & \multicolumn{1}{c}{ By obtain } \\
\hline inch (in.) & Length & \\
foot (ft) & 25.4 & millimeter $(\mathrm{mm})$ \\
mile (mi) & 0.3048 & meter $(\mathrm{m})$ \\
& 1.609 & kilometer $(\mathrm{km})$ \\
\hline square mile $\left(\mathrm{mi}^{2}\right)$ & Area & \\
\hline & 2.590 & square kilometer $\left(\mathrm{km}^{2}\right)$ \\
\hline cubic foot $\left(\mathrm{ft}^{3}\right)$ & Volume & \\
\hline & 0.02832 & cubic meter $\left(\mathrm{m}^{3}\right)$ \\
\hline cubic foot per second $\left(\mathrm{ft}^{3} / \mathrm{s}\right)$ & Flow rate & cubic meter per second $\left(\mathrm{m}^{3} / \mathrm{s}\right)$ \\
\hline
\end{tabular}

Horizontal coordinate information is referenced to the North American Datum of 1983 (NAD 83).

The water year (WY) begins October 1 and ends September 30 of the following year. The WY is designated by the calendar year in which it ends; for example, WY 2014 begins on 0ctober 1 , 2013, and ends on September 30, 2014. 


\title{
Simulation of Daily Streamflow for Nine River Basins in Eastern lowa Using the Precipitation-Runoff Modeling System
}

\author{
By Adel E. Haj, Daniel E. Christiansen, and Kasey J. Hutchinson
}

\section{Abstract}

The U.S. Geological Survey, in cooperation with the Iowa Department of Natural Resources, constructed Precipitation-Runoff Modeling System models to estimate daily streamflow for nine river basins in eastern Iowa that drain into the Mississippi River. The models are part of a suite of methods for estimating daily streamflow at ungaged sites. The Precipitation-Runoff Modeling System is a deterministic, distributed-parameter, physical-process-based modeling system developed to evaluate the response of streamflow and general drainage basin hydrology to various combinations of climate and land use. Calibration and validation periods used in each basin mostly were October 1, 2002, through September 30, 2012, but differed depending on the period of record available for daily mean streamflow measurements at U.S. Geological Survey streamflow-gaging stations.

A geographic information system tool was used to delineate each basin and estimate values for model parameters based on basin physical and geographical features. A U.S. Geological Survey auto-calibration tool that uses a shuffled complex evolution algorithm was used for initial calibration, and then manual modifications were made to parameter values to complete the calibration of each basin model. The main objective of the calibration was to match daily discharge values of simulated streamflow to measured daily discharge values.

The accuracy of Precipitation-Runoff Modeling System model streamflow estimates of nine river basins in eastern Iowa as compared to measured values at U.S. Geological Survey streamflow-gaging stations varied. The PrecipitationRunoff Modeling System models of nine river basins in eastern Iowa were satisfactory at estimating daily streamflow at 57 of the 79 calibration sites and 13 of the 14 validation sites based on statistical results. Unsatisfactory performance can be contributed to several factors: (1) low flow, no flow, and flashy flow conditions in headwater subbasins having a small drainage area; (2) poor representation of the groundwater and storage components of flow within a basin; (3) lack of accounting for basin withdrawals and water use; and (4) the availability and accuracy of meteorological input data. The PrecipitationRunoff Modeling System models of nine river basins in eastern Iowa will provide water-resource managers with a consistent and documented method for estimating streamflow at ungaged sites and aid in environmental studies, hydraulic design, water management, and water-quality projects.

\section{Introduction}

The U.S. Geological Survey (USGS), in cooperation with State, county, municipal, and other Federal agencies, collects a large amount of data pertaining to the water resources of Iowa each year. These data constitute a valuable database for developing an improved understanding of State water resources. Surface-water data for Iowa include records of stage, discharge, and water quality of streams and records of stage of lakes and reservoirs. Iowa has 71,000 miles (mi) of rivers and streams (Iowa Department of Natural Resources, 2000), and measurements collected from USGS streamflow-gaging stations on those streams (gaged sites) only account for a very narrow representation of the surface-water flow in the State. There is a strong need by water-resource managers of the Iowa Department of Natural Resources (IDNR) for a consistent and documented method for providing streamflow estimates in Iowa at locations where no USGS streamflow-gaging station is present (ungaged sites). Streamflow estimates at ungaged sites would aid water-resource managers in environmental studies, hydraulic design, water management, and water-quality projects.

The USGS maintains about 149 real-time streamflowgaging stations in Iowa where daily mean streamflow information is available (U.S. Geological Survey, 2014). This streamflow information provides the basis for understanding the hydrologic characteristics of drainage basins (basins), and, in combination with water-quality information collected at a monthly time step at 75 locations across the State by State and Federal agencies, aids in the understanding of risks imposed on human and ecosystem health. Because the information collected at gaged sites is site specific, the ability to confidently 
use these data to infer information at ungaged sites within a basin for adaptive management and decisions can be limited.

Hydrological models are one tool that can be used to overcome the lack of hydrologic information at ungaged sites in eastern Iowa (Christiansen, 2012). Precipitation-Runoff Modeling System (PRMS) models (Leavesley and others, 1983; Markstrom and others, 2008; Markstrom and others, 2015) were constructed, in cooperation with the IDNR, for nine river basins in eastern Iowa as part of an ongoing research project to examine methods of estimating daily streamflow at gaged and ungaged sites. Hydrological models can be combined with other predictive methods and techniques, such as the Flow Duration Curve Transfer and the Flow Anywhere methods (Linhart and others, 2013), to provide a comprehensive approach in developing near real-time streamflow estimates.

\section{Purpose and Scope}

This report describes the use of the USGS PRMS (Leavesley and others, 1983; Markstrom and others, 2008; Markstrom and others, 2015) for simulating daily streamflow in nine eastern Iowa River basins draining into the Mississippi River. The construction, calibration, and evaluation of PRMS models of nine river basins in eastern Iowa to simulate daily streamflow at gaged and ungaged sites are described. Model performance is assessed to determine the ability of PRMS to estimate streamflow and, thus, the suitability for the model to serve as part of a suite of methods for estimating daily streamflow at ungaged sites. Model limitations are investigated and described.

\section{Description of Study Areas}

The PRMS models were constructed for a total of nine river basins in eastern Iowa that are tributaries to the Mississippi River: Upper Iowa River Basin, Yellow River Basin, Turkey River Basin, Maquoketa River Basin, Wapsipinicon River Basin, Iowa River Basin, Skunk River Basin, Des Moines River Basin, and Fox River Basin (figs. 1 and 2). Although the percentage varies, all basins are dominated by agriculture in the form of corn and soybeans (U.S. Department of Agriculture, 2014). There are livestock operations (including beef and dairy cattle, hogs, sheep, and poultry) in varying amounts in each of the nine river basins in eastern Iowa. In addition, tile drainage is extensive throughout each basin to enhance crop production by removing excess water from the soil. The eastern part of the State spans seven of Iowa's landform regions, and each has a characteristic topography and glacial history (Prior and others, 2009; Prior, 1991) (fig. 1).

The first of these nine basins in eastern Iowa, the Upper Iowa River Basin, is in northeast Iowa, drains about 1,005 square miles $\left(\mathrm{mi}^{2}\right)$, and extends from its headwaters in Mower County, Minnesota, to the Mississippi River in northeast Allamakee County, Iowa (figs. 1 and 2). The Upper
Iowa River Basin is in an area of the State characterized by rugged hills, steep topography, a complex network of springs, and diverse land use. Most of the Upper Iowa River Basin is within the Paleozoic Plateau landform region; the western part of the Upper Iowa River Basin is within the Iowan Surface landform region (fig. 1). Three USGS streamflow-gaging stations in the Upper Iowa River Basin were used in this study (table 1; fig. 2).

The Yellow River Basin originates in southwestern Winneshiek County, northeast Iowa, and drains about $240 \mathrm{mi}^{2}$ before its confluence with the Mississippi River in Allamakee County, Iowa (fig. 1). The Yellow River Basin is within the Paleozoic Plateau (figs. 1 and 2). The Yellow River Basin is mainly forest or agricultural land with little urban development (Iowa Department of Natural Resources, 2009). One USGS streamflow-gaging station in the Yellow River Basin was used in this study (table 1; fig. 2).

The Turkey River Basin originates in Howard County, northeast Iowa, and drains about 1,685 $\mathrm{mi}^{2}$ into the Mississippi River in Clayton County, Iowa (figs. 1 and 2). The upper part of the Turkey River Basin is within the Iowan Surface, and the lower part lies within the Paleozoic Plateau (fig. 1). Six USGS streamflow-gaging stations in the Turkey River Basin were used in this study (table 1; fig. 2).

The Maquoketa River Basin drains about 1,880 $\mathrm{mi}^{2}$ in northeast Iowa, originates in Fayette County, Iowa, and flows southeast to the Mississippi River in Jackson County, Iowa (figs. 1 and 2). The Maquoketa River Basin consists of the Iowan Surface and East-Central Iowa Drift Plain landform regions, and a small part in the northeast extends into the Paleozoic Plateau (fig. 1). Three USGS streamflow-gaging stations in the Maquoketa River Basin were used in this study (table 1; fig. 2).

The Wapsipinicon River Basin drains 2,540 mi², originates in Mower County, southeastern Minnesota, and extends about $225 \mathrm{mi}$ southeast to its confluence with the Mississippi River (figs. 1 and 2). Most of the Wapsipinicon River Basin lies within the Iowan Surface, but small parts cross into the East-Central Iowa Drift Plain and Southern Iowa Drift Plain landform region in the eastern part of the Wapsipinicon River Basin near the outlet (fig. 1). Seven USGS streamflow-gaging stations in the Wapsipinicon River Basin were used in this study (table 1; fig. 2).

The Iowa River Basin drains about 12,640 $\mathrm{mi}^{2}$ and extends from its headwaters in southern Minnesota to its outlet in Louisa County, southern Iowa (fig. 1). The Cedar River is the largest tributary to the Iowa River and drains about $7,815 \mathrm{mi}^{2}$ before its confluence. The Iowa River Basin is the second largest basin in Iowa that extends into the Des Moines Lobe landform region in the northwest part, the Iowan Surface in the central and eastern parts, and the Southern Iowa Drift Plain and the Iowa-Cedar Lowland in the southern part of the basin (fig. 1). Cedar Rapids, Waterloo, and Iowa City, Iowa, are the primary urban centers within the Iowa River Basin. A total of 33 USGS streamflow-gaging stations in the Iowa River Basin were used in this study (table 1; fig. 2). 


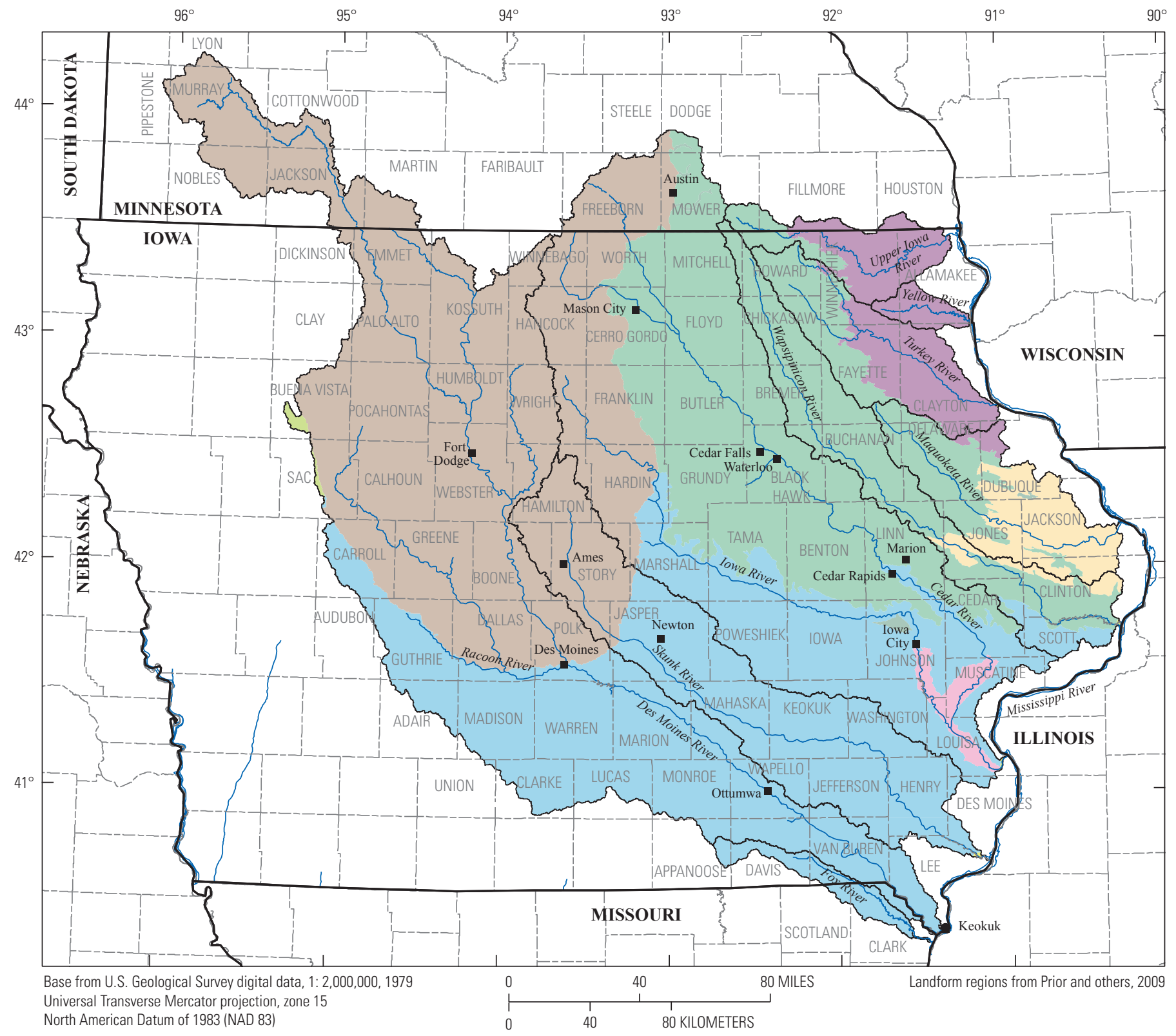

EXPLANATION

\begin{tabular}{|l|l|}
\hline lowa landform regions & \multicolumn{1}{c}{ Basin boundary-Precipitation-Runoff } \\
Des Moines Lobe & Moding System \\
\hline & East-Central lowa Drift Plain \\
\hline lowa-Cedar Lowland \\
lowan Surface \\
Northwest lowa Plains \\
Paleozoic Plateau \\
Southern lowa Drift Plain
\end{tabular}

Figure 1. Landform regions for Precipitation-Runoff Modeling System models of nine river basins in eastern lowa. 


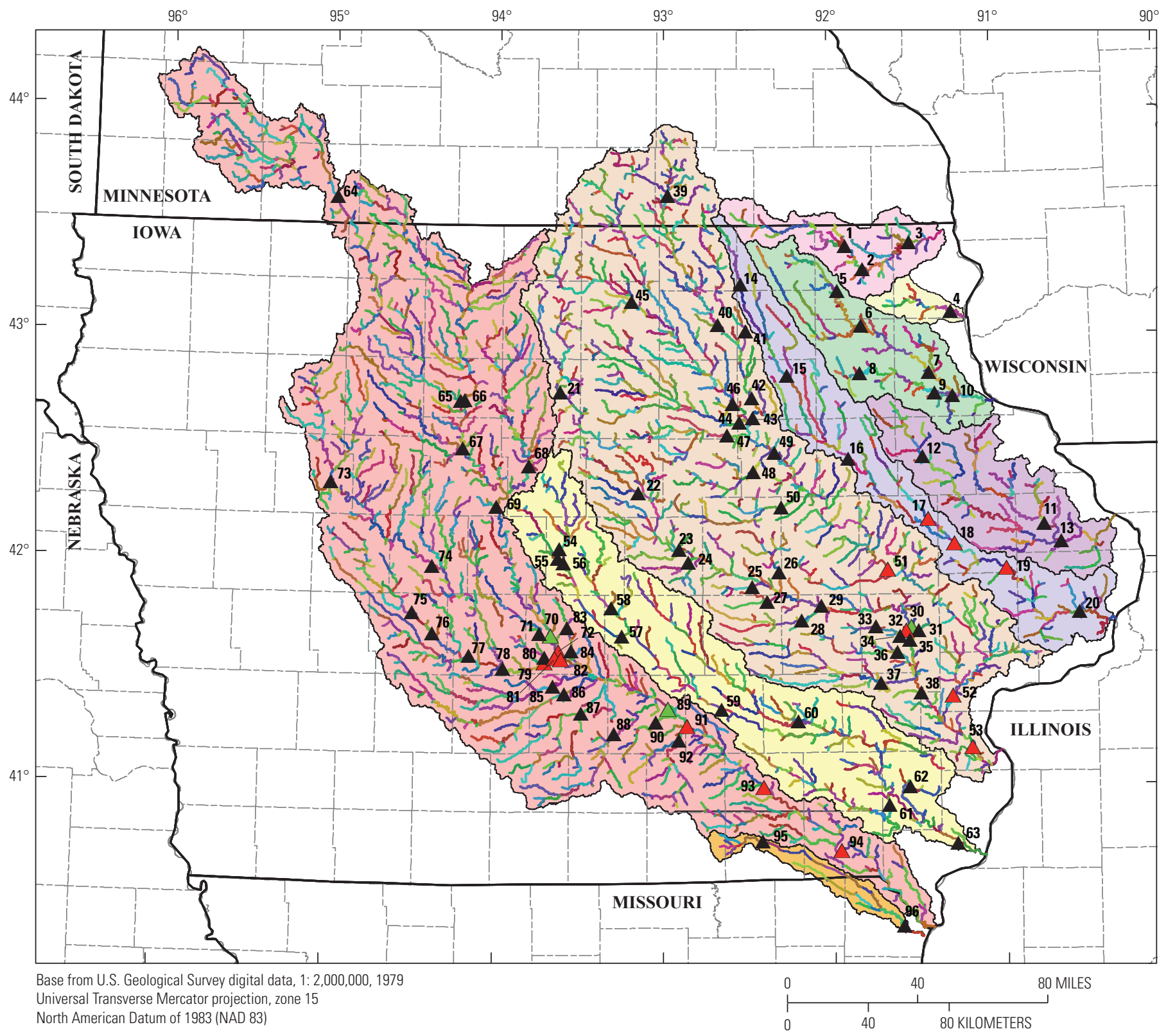

EXPLANATION

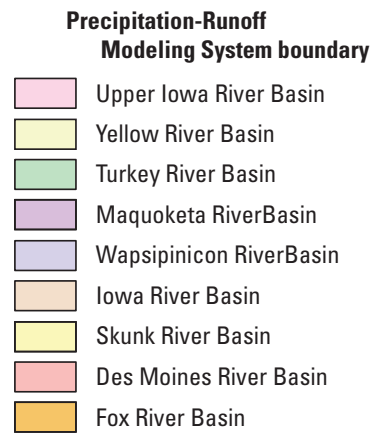

_ Stream segments-Each color represents a simulated stream segment

Streamflow-gaging station type and map number (table 1)

64 Calibration location

$93 \triangle$ Validation location

$70 \triangle$ Input location

Figure 2. Simulated stream segments and U.S. Geological Survey streamflow-gaging stations providing measured data for Precipitation-Runoff Modeling System models of nine river basins in eastern lowa. 
Table 1. U.S. Geological Survey streamflow-gaging stations used for input, calibrating, and validating the Precipitation-Runoff Modeling System models of nine river basins in eastern lowa.

[USGS, U.S. Geological Survey; latitude and longitude in decimal degrees; mi², square miles; IA, Iowa; Cr, creek; NE, Northeast; nr, near; MN, Minnesota; DS, downstream; MO, Missouri]

\begin{tabular}{|c|c|c|c|c|c|c|}
\hline $\begin{array}{c}\text { Map } \\
\text { number } \\
\text { (fig. 2) }\end{array}$ & $\begin{array}{c}\text { USGS } \\
\text { station } \\
\text { number }\end{array}$ & USGS station name & $\begin{array}{c}\text { Latitude } \\
\text { (north) }\end{array}$ & $\begin{array}{c}\text { Longitude } \\
\text { (west) }\end{array}$ & $\begin{array}{c}\text { Drainage } \\
\text { area } \\
\text { measured } \\
\text { at gage } \\
\left(\mathrm{mi}^{2}\right) \\
\end{array}$ & Period of record used \\
\hline \multicolumn{7}{|c|}{ Upper lowa River Basin } \\
\hline 1 & 05387440 & Upper Iowa River at Bluffton, IA & 43.4069 & 91.8990 & 367 & $10 / 01 / 2002-09 / 30 / 2012$ \\
\hline \multicolumn{7}{|c|}{$\begin{array}{lll} & \text { Yellow River Basin } \\
\end{array}$} \\
\hline 4 & 05389000 & Yellow River near Ion, IA & 43.1119 & 91.2651 & 221 & $10 / 01 / 2004-09 / 30 / 2012$ \\
\hline \multicolumn{7}{|c|}{ Turkey River Basin } \\
\hline 5 & 05411600 & Turkey River at Spillville, IA & 43.2073 & 91.9503 & 177 & 05/01/2010-09/30/2012 \\
\hline 9 & 05412400 & Volga River at Littleport, IA & 42.7539 & 91.3690 & 348 & $10 / 01 / 2002-09 / 30 / 2012$ \\
\hline 10 & 05412500 & Turkey River at Garber, IA & 42.7400 & 91.2618 & 1,545 & $10 / 01 / 2002-09 / 30 / 2012$ \\
\hline \multicolumn{7}{|c|}{ Maquoketa River Basin } \\
\hline 11 & 05416900 & Maquoketa River at Manchester, IA & 42.1643 & 90.7293 & 275 & 06/23/2003-09/30/2012 \\
\hline 12 & 05418400 & North Fork Maquoketa River near Fulton, IA & 42.4700 & 91.4487 & 505 & $10 / 01 / 2002-09 / 30 / 2012$ \\
\hline 13 & 05418500 & Maquoketa River near Maquoketa, IA & 42.0834 & 90.6329 & 1,553 & $10 / 01 / 2002-09 / 30 / 2012$ \\
\hline \multicolumn{7}{|c|}{ Wapsipinicon River Basin } \\
\hline 14 & 05420560 & Wapsipinicon River near Elma, IA & 43.2416 & 92.5331 & 95.2 & $10 / 01 / 1981-09 / 30 / 1992$ \\
\hline \multicolumn{7}{|c|}{ lowa River Basin } \\
\hline 21 & 05449500 & Iowa River near Rowan, IA & 42.7599 & 93.6218 & 429 & $10 / 01 / 2002-09 / 30 / 2012$ \\
\hline 22 & 05451210 & South Fork Iowa River NE of New Providence, IA & 42.3151 & 93.1521 & 224 & $10 / 01 / 2002-09 / 30 / 2012$ \\
\hline 23 & 05451500 & Iowa River at Marshalltown, IA & 42.0658 & 92.9077 & 1,532 & $10 / 01 / 2002-09 / 30 / 2012$ \\
\hline 24 & 05451700 & Timber Creek near Marshalltown, IA & 42.0089 & 92.8524 & 118 & $10 / 01 / 2002-09 / 30 / 2012$ \\
\hline 25 & 05451900 & Richland Creek near Haven, IA & 41.8994 & 92.4744 & 56.1 & $10 / 01 / 2002-09 / 30 / 2012$ \\
\hline 26 & 05452000 & Salt Creek near Elberon, IA & 41.9642 & 92.3132 & 201 & $10 / 01 / 2002-09 / 30 / 2012$ \\
\hline 27 & 05452200 & Walnut Creek near Hartwick, IA & 41.8350 & 92.3863 & 70.9 & $10 / 01 / 2002-09 / 30 / 2012$ \\
\hline 28 & 05453000 & Big Bear Creek at Ladora, IA & 41.7494 & 92.1821 & 189 & $10 / 01 / 2002-09 / 30 / 2012$ \\
\hline 29 & 05453100 & Iowa River at Marengo, IA & 41.8127 & 92.0648 & 2,794 & $10 / 01 / 2002-09 / 30 / 2012$ \\
\hline 30 & 05453520 & Iowa River below Coralville Dam nr Coralville, IA $^{1}$ & 41.7153 & 91.5302 & 3,115 & $10 / 01 / 2002-09 / 30 / 2012$ \\
\hline 31 & 05454000 & Rapid Creek near Iowa City, IA & 41.7000 & 91.4877 & 25.3 & $10 / 01 / 2002-09 / 30 / 2012$ \\
\hline 32 & 05454090 & Muddy Creek at Coralville, IA & 41.7000 & 91.5628 & 8.7 & $10 / 01 / 2002-09 / 30 / 2012$ \\
\hline
\end{tabular}


Table 1. U.S. Geological Survey streamflow-gaging stations used for input, calibrating, and validating the Precipitation-Runoff Modeling System models of nine river basins in eastern lowa.-Continued

[USGS, U.S. Geological Survey; latitude and longitude in decimal degrees; mi², square miles; IA, Iowa; Cr, creek; NE, Northeast; nr, near; MN, Minnesota; DS, downstream; MO, Missouri]

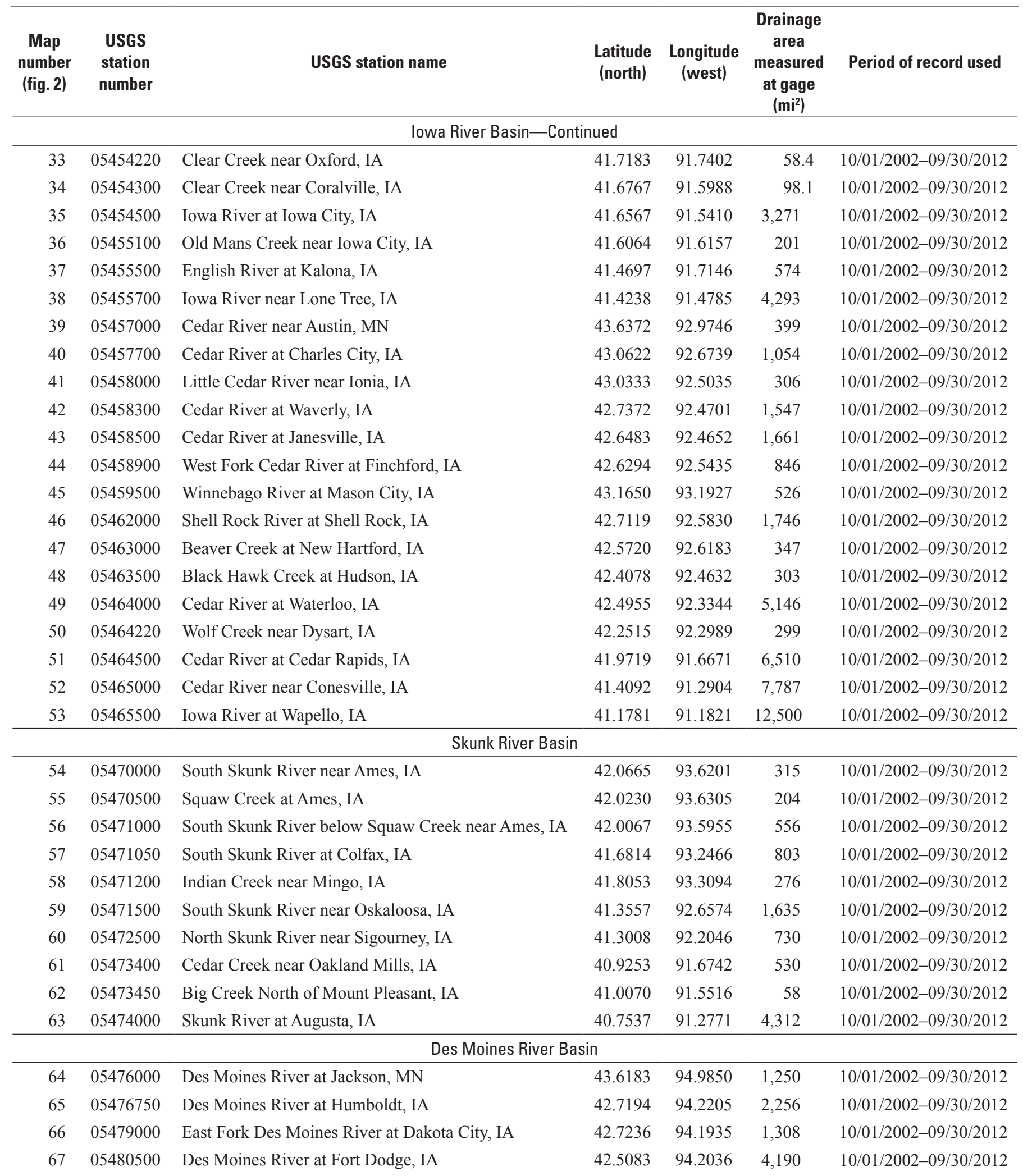


Table 1. U.S. Geological Survey streamflow-gaging stations used for input, calibrating, and validating the Precipitation-Runoff Modeling System models of nine river basins in eastern lowa.-Continued

[USGS, U.S. Geological Survey; latitude and longitude in decimal degrees; mi², square miles; IA, Iowa; Cr, creek; NE, Northeast; nr, near; MN, Minnesota; DS, downstream; MO, Missouri]

\begin{tabular}{|c|c|c|c|c|c|c|}
\hline $\begin{array}{c}\text { Map } \\
\text { number } \\
\text { (fig. 2) }\end{array}$ & $\begin{array}{c}\text { USGS } \\
\text { station } \\
\text { number }\end{array}$ & USGS station name & $\begin{array}{l}\text { Latitude } \\
\text { (north) }\end{array}$ & $\begin{array}{l}\text { Longitude } \\
\text { (west) }\end{array}$ & $\begin{array}{l}\text { Drainage } \\
\text { area } \\
\text { measured } \\
\text { at gage } \\
\left(\mathrm{mi}^{2}\right)\end{array}$ & Period of record used \\
\hline \multicolumn{7}{|c|}{ Des Moines River Basin-Continued } \\
\hline 68 & 05481000 & Boone River near Webster City, IA & 42.4325 & 93.8058 & 844 & $10 / 01 / 2002-09 / 30 / 2012$ \\
\hline 70 & 05481650 & Des Moines River near Saylorville, $\mathrm{IA}^{1}$ & 41.6805 & 93.6683 & 5,841 & $10 / 01 / 2002-09 / 30 / 2012$ \\
\hline 71 & 05481950 & Beaver Creek near Grimes, IA & 41.6883 & 93.7355 & 358 & $10 / 01 / 2002-09 / 30 / 2012$ \\
\hline 72 & 05482000 & Des Moines River at 2nd Avenue at Des Moines, IA & 41.6125 & 93.6210 & 6,245 & $10 / 01 / 2002-09 / 30 / 2012$ \\
\hline 73 & 05482300 & North Raccoon River near Sac City, IA & 42.3548 & 94.9903 & 700 & $10 / 01 / 2002-09 / 30 / 2012$ \\
\hline 74 & 05482500 & North Raccoon River near Jefferson, IA & 41.9880 & 94.3769 & 1,619 & $10 / 01 / 2002-09 / 30 / 2012$ \\
\hline 78 & 05484500 & Raccoon River at Van Meter, IA & 41.5339 & 93.9500 & 3,441 & $10 / 01 / 2002-09 / 30 / 2012$ \\
\hline 79 & 05484650 & Raccoon River at 63rd Street at Des Moines, IA & 41.5617 & 93.7036 & 3,529 & $10 / 01 / 2002-09 / 30 / 2012$ \\
\hline 80 & 05484800 & Walnut Creek at Des Moines, IA & 41.5872 & 93.7033 & 78.4 & $10 / 01 / 2002-09 / 30 / 2012$ \\
\hline 81 & 05484900 & Raccoon River at Fleur Drive at Des Moines, IA & 41.5817 & 93.6430 & 3,625 & $10 / 01 / 2002-09 / 30 / 2012$ \\
\hline 82 & 05485500 & $\begin{array}{l}\text { Des Moines River below Raccoon River at Des Moines, } \\
\text { IA }\end{array}$ & 41.5778 & 93.6055 & 9,879 & $10 / 01 / 2002-09 / 30 / 2012$ \\
\hline 83 & 05485605 & Fourmile Creek near Ankeny, IA DS1 & 41.7174 & 93.5701 & 62.0 & $10 / 01 / 2003-09 / 30 / 2012$ \\
\hline 84 & 05485640 & Fourmile Creek at Des Moines, IA & 41.6139 & 93.5455 & 92.7 & $10 / 01 / 2002-09 / 30 / 2012$ \\
\hline 85 & 05486000 & North River near Norwalk, IA & 41.4579 & 93.6550 & 349 & $10 / 01 / 2002-09 / 30 / 2012$ \\
\hline 91 & 05488500 & Des Moines River near Tracy, IA & 41.2814 & 92.8615 & 12,479 & $10 / 01 / 2002-09 / 30 / 2012$ \\
\hline 92 & 05489000 & Cedar Creek near Bussey, IA & 41.2190 & 92.9085 & 374 & $10 / 01 / 2002-09 / 30 / 2012$ \\
\hline 93 & 05489500 & Des Moines River at Ottumwa, IA & 41.0108 & 92.4113 & 13,374 & $10 / 01 / 2002-09 / 30 / 2012$ \\
\hline 94 & 05490500 & Des Moines River at Keosauqua, IA & 40.7278 & 91.9596 & 14,038 & $10 / 01 / 2002-09 / 30 / 2012$ \\
\hline \multicolumn{7}{|c|}{ Fox River Basin } \\
\hline 95 & 05494300 & Fox River at Bloomfield, IA & 40.7695 & 92.4188 & 87.7 & $10 / 01 / 2002-09 / 30 / 2012$ \\
\hline 96 & 05495000 & Fox River at Wayland, MO & 40.3924 & 91.5979 & 400 & $10 / 01 / 2002-09 / 30 / 2012$ \\
\hline
\end{tabular}

${ }^{1}$ Sites used for historical streamflows. 
Simulation of Daily Streamflow for Nine River Basins in Eastern lowa Using the Precipitation-Runoff Modeling System

The Skunk River Basin drains about 4,355 $\mathrm{mi}^{2}$ southeast into the Mississippi River and extends from Hamilton County, central Iowa, to Des Moines and Lee Counties, southeast Iowa (figs. 1 and 2). Most of the Skunk River Basin is in the Southern Iowa Drift Plain, but the most northern part is within the Des Moines Lobe (fig. 1). The largest metropolitan areas in the Skunk River Basin are Ames and Newton, Iowa. A total of 10 USGS streamflow-gaging stations in the Skunk River Basin were used in this study (table 1; fig. 2).

The Des Moines River Basin drains about 14,470 $\mathrm{mi}^{2}$ and extends from its headwaters in southwest Minnesota to its outlet near Keokuk, southeast Iowa (fig. 1). The Raccoon River drains about 3,625 $\mathrm{mi}^{2}$ and is the largest tributary to the Des Moines River. The Des Moines River Basin lies within the Des Moines Lobe in the northern part, and the Southern Iowa Drift Plain in the remainder of the basin (fig. 1). The Des Moines metropolitan area, Fort Dodge, and Ottumwa, Iowa, are the largest urban centers within the Des Moines River Basin. A total of 31 USGS streamflow-gaging stations in the Des Moines River Basin were used in this study (table 1; fig. 2).

The Fox River Basin drains about $405 \mathrm{mi}^{2}$ of southeast Iowa and northeast Missouri to the Mississippi River. The Fox River Basin lies within the Southern Iowa Drift Plain (fig. 1). The Fox River Basin is mainly agricultural land with little urban development. Two USGS streamflow-gaging stations in the Fox River Basin were used in this study (table 1; fig. 2).

\section{Model Development}

The PRMS is a deterministic, distributed-parameter, physical-process-based modeling system developed to evaluate the response of streamflow and general basin hydrology to various combinations of climate and land use (Markstrom and others, 2015). The PRMS simulates the hydrologic system with known physical laws and empirical relations derived from basin characteristics (Markstrom and others, 2008). The PRMS is designed to account for spatially distributed parameters and basin characteristics. A schematic diagram of how basin and climate inputs are simulated in a typical PRMS model is shown in figure 3.

In PRMS, a basin is divided into a series of contiguous spatial units called hydrologic response units (HRUs) based on hydrologic and physical characteristics such as land surface altitude, slope, aspect, plant type and cover, land use, soil morphology, geology, drainage boundaries, distribution of precipitation, temperature, solar radiation, and flow direction (Markstrom and others, 2008). The HRUs receive and produce streamflow to and from each other, and to the drainage network consisting of stream segments (Goode and others, 2010). Individual HRUs are considered homogenous with respect to hydrologic and physical characteristics, and storage components are instantaneously and fully mixed. Energy and water balance are computed by PRMS daily for each HRU (Markstrom and others, 2008).

The PRMS models of nine river basins in eastern Iowa were constructed in several steps, which included the compilation of necessary datasets, the delineation of HRU boundaries to accommodate the stream network and provide streamflows at specific locations for calibration and validation, and the parameterization of model HRUs and stream segments. This section describes the procedures used to prepare input datasets, basin discretization, and parameterization for the PRMS models of nine river basins in eastern Iowa.

\section{Delineation and Parameterization of Spatial Features}

For this study, a geospatial database was created for use within a geographic information system (GIS) to support model discretization, characterize the physical features of the basins, and estimate PRMS model parameters. The geospatial database consisted of the National Land Cover Database, Percent Impervious, U.S. Forest types, U.S. Forest Density, State Soil Geographic Database (STATSGO) general soil maps, and a digital elevation model (DEM) derived from the USGS National Elevation Dataset (NED) (U.S. Geological Survey, 2007; Homer and others, 2007; U.S. Department of Agriculture, 1994).

The GIS Weasel (Viger and Leavesley, 2007) was used to delineate, characterize the physical features of, and estimate initial parameter values for input into PRMS models of nine river basins in eastern Iowa. The DEMs were processed by the GIS Weasel, which created raster datasets of flow direction and flow accumulation. A drainage network was extracted from this surface by finding all points at which the flow accumulation is equal to or greater than a user-specified threshold (Viger and Leavesley, 2007). Each drainage network was segmented at stream tributaries from headwater to the confluence with the Mississippi River. An interactive process in the GIS Weasel was used to discretize the HRUs based on the drainage network dataset and location of USGS streamflowgaging stations (Viger and Leavesley, 2007). Two-plane HRUs are developed to separate contributing areas from left and right banks of each stream segment. The Upper Iowa River Basin model discretization consists of 66 stream segments and 132 HRUs; the Yellow River Basin model discretization consists of 17 stream segments and 34 HRUs; the Turkey River Basin model discretization consists of 91 stream segments and 186 HRUs; the Maquoketa River Basin model discretization consists of 98 stream segments and 195 HRUs; the Wapsipinicon River Basin model discretization consists of 133 stream segments and 265 HRUs; the Iowa River Basin model discretization consists of 1,174 stream segments and 2,340 HRUs; the Skunk River Basin model discretization consists of 275 stream segments and 550 HRUs; the Des Moines River Basin model discretization consists of 1,308 stream segments and 


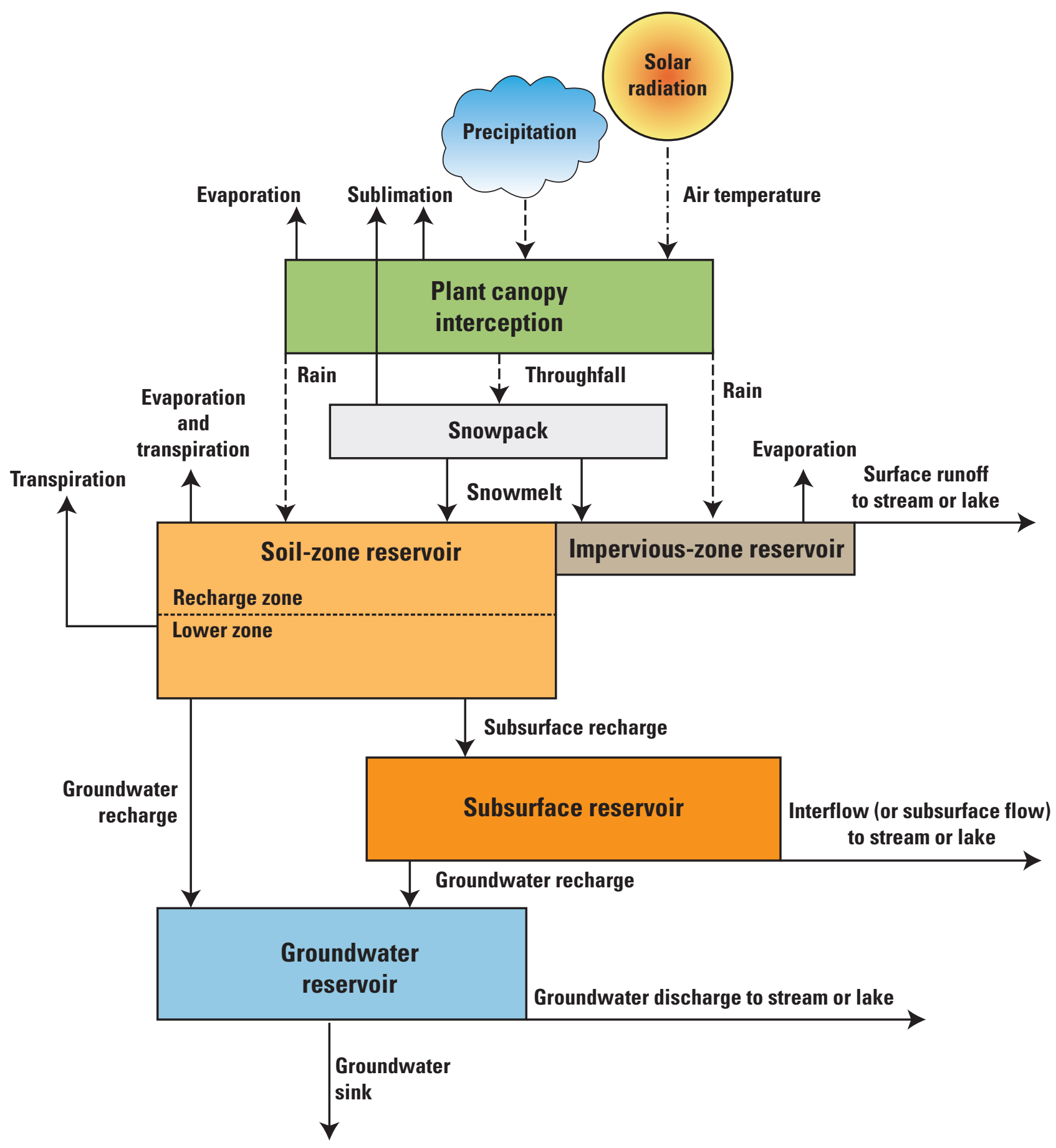

Modified from Markstrom and others, 2008

Figure 3. Schematic diagram of a basin and its meteorological inputs (precipitation, air temperature, and solar radiation) simulated by the Precipitation-Runoff Modeling System. 
2,627 HRUs; and the Fox River Basin model discretization consists of 20 stream segments and 40 HRUs (figs. 2 and 4).

\section{Model Input and Measured Data}

The PRMS can use many meteorological inputs. Precipitation, minimum temperature, and maximum temperature were used in the PRMS models of nine river basins in eastern Iowa as the main climatic drivers. In addition to meteorological inputs, PRMS also can use streamflow-gaging station data in place of simulated streamflow. This is especilly useful where flows are heavily affected by upstream regulation. The Iowa River and Des Moines River Basin models used streamflowgaging station data as input at USGS streamflow-gaging stations 05453520,05481650 , and 05488110 to accurately account for outflows from upstream reservoirs during simulations (table 1; fig. 2).

The USGS streamflow-gaging station data and meteorological datasets for precipitation and temperature were prepared using the USGS Downsizer program (Ward-Garrison and others, 2009). The Downsizer program is a computer application that selects, downloads, verifies, and formats station-based time-series data for PRMS and other environmental modeling programs. The quality-control dialog in Downsizer was used to select National Oceanic and Atmospheric Administration's National Weather Service Cooperative Observer Program meteorological stations that had data from January 1, 1980, through September 30, 2012 (National Oceanic and Atmospheric Administration, 2014). Meteorological stations that had large amounts of missing or bad data values were removed from the PRMS input data list, and stations with period of record from October 1, 2002, through September 30, 2012 were retained. The Downsizer software program also was used to retrieve USGS streamflow-gaging station daily mean streamflow observations at gaged sites in the model areas from October 1, 1980, through September 30, 2012. Gaged sites were selected based on being in current operation, having a minimum period of record of 5 years, and having a period of record from October 1, 2002, through September 30, 2012, with a few exceptions (table 1). The 96 USGS streamflow-gaging stations and 155 meteorological stations included in the PRMS model data files of nine river basins in eastern Iowa are listed in tables 1-2 and shown in figures 2 and 4 .

\section{Model Calibration, Validation, and Evaluation}

Calibration and validation periods used in each basin mostly were October 1, 2002, through September 30, 2012. The calibration or validation period differed depending on the period of record available for daily mean streamflow measurements at U.S. Geological Survey streamflow-gaging stations (table 1).

The PRMS model was calibrated using the Luca computer program (Hay and Umemoto, 2006). Luca is a graphical user interface that provides a simple, systematic way of implementing a multiple-objective, stepwise calibration of the PRMS model parameters. Luca uses the Shuffled Complex Evolution (SCE) (Duan and others, 1993) global search algorithm to calibrate model parameters. Luca has been used by researchers to calibrate many PRMS models (Hay and Umemoto 2006; Dudley, 2008; Goode and others, 2010; Christiansen, 2012; LaFontaine and others, 2013; Haj and others, 2014).

In this study, Luca was used to complete a multipleobjective, stepwise calibration of the PRMS models of nine river basins in eastern Iowa. A total of 79 USGS streamflowgaging stations throughout the nine river basins in eastern Iowa were used for calibration with emphasis on matching model simulated daily streamflow with measured daily streamflow (fig. 2; table 3). The Luca calibration includes three objective functions - low, high, and mean flows - in an effort to accurately represent all flow regimes. A basin-wide, sixstep calibration of climate and streamflow related parameters (table 4) was initially completed, and additional calibration of subbasin streamflow parameters (table 4) was completed at selected gaged sites (table 3) to increase the parameter resolution and accuracy. Of the remaining 17 gaged sites (tables 1 and 3), data from 3 were used for input to account for outflows from reservoirs (as discussed in "Model Input and Measured Data"), and data from 14 were used for model validation to demonstrate potential accuracy of model estimated daily streamflows at ungaged sites.

Statistical tests were used to evaluate how well each PRMS model of the nine river basins in eastern Iowa estimated daily streamflow. The Nash Sutcliffe efficiency (NSE), coefficient of determination $\left(\mathrm{R}^{2}\right)$, percent bias (PBIAS), and root mean square error-observation standard deviation ratio (RSR) statistics (Moriasi and others, 2007; Singh and others, 2004; Nash and Sutcliffe, 1970) were used to evaluate model performance. The NSE is a normalized statistic that provides a measure of how well simulated values match measured datasets. The NSE values range from $-\infty$ to 1 . Values of 0 or less indicate that the mean measured streamflow is a better predictor than simulated streamflows. A value of 0.0 indicates the simulated streamflow is as good as using the average value of all the measured data, and a value of 1 indicates a perfect fit between measured and simulated values. Moriasi and others (2007) suggest that a monthly NSE of greater than 0.50 is satisfactory in basin models such as PRMS. Although daily values may be lower than 0.50 and still hold a satisfactory rating, an NSE value of greater than 0.50 is considered satisfactory.

The $R^{2}$ evaluates how accurately the model tracks the variability in the measured data that is explained by the simulated data. The $R^{2}$ can reveal the strength of the linear relationship between the predicted and the measured values. It can range from 0 and 1 , and the closer the value is to 1 the better the linear correlation between simulated and measured values (Kalin and Hantush, 2006). Values above 0.5 are considered to be satisfactory (Gassman and others, 2007).

The PBIAS measures the average tendency of the simulated data to be larger or smaller than their observed 


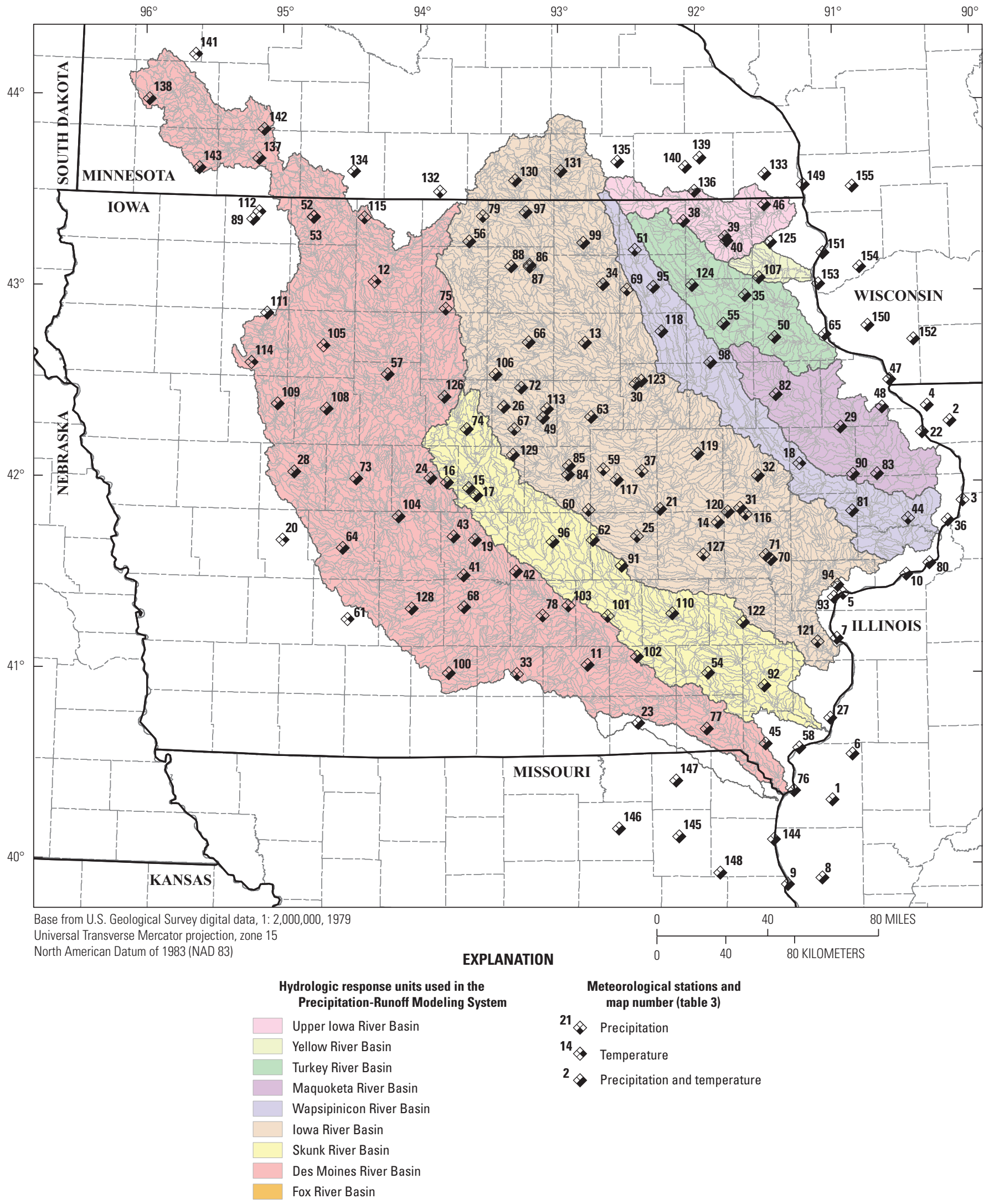

Figure 4. National Oceanic and Atmospheric Administration's National Weather Service Cooperative Observer Program meteorological stations and hydrologic response units used in the Precipitation-Runoff Modeling System models or nine river basins in eastern lowa. 


\section{Simulation of Daily Streamflow for Nine River Basins in Eastern lowa Using the Precipitation-Runoff Modeling System}

Table 2. National Oceanic and Atmospheric Administration's National Weather Service Cooperative Observer Program meteorological stations used in the Precipitation-Runoff Modeling System models of nine river basins in eastern lowa.

[Latitude and longitude in decimal degrees; IL, Illinois; NNE, north, northeast; IA, Iowa; W, west; WSW, west, southwest; SE, southeast; WNW, west, northwest; S, south; E, east; NE, northeast; Wsfo, weather service forecast office; N, north; ft, fort; Mt, Mount; NNW, north, northwest; SW, southwest; NW, northwest; SSW, south, southwest; MN, Minnesota; MO, Missouri; WI, Wisconsin]

\begin{tabular}{|c|c|c|c|c|c|c|}
\hline $\begin{array}{c}\text { Map } \\
\text { number } \\
\text { (fig. 4) }\end{array}$ & $\begin{array}{l}\text { Station } \\
\text { number }\end{array}$ & Meteorological station name & $\begin{array}{l}\text { Latitude } \\
\text { (north) }\end{array}$ & $\begin{array}{c}\text { Longitude } \\
\text { (west) }\end{array}$ & Elevation & Period of record used \\
\hline 1 & 110598 & Bentley, IL & 40.3444 & 91.1125 & 650.00 & $10 / 01 / 2001-09 / 30 / 2012$ \\
\hline 2 & 112745 & Elizabeth, IL & 42.3161 & 90.2269 & 675.00 & $10 / 01 / 2001-09 / 30 / 2012$ \\
\hline 3 & 113290 & Fulton Dam, IL & 41.8978 & 90.1544 & 592.00 & $10 / 01 / 2001-09 / 30 / 2012$ \\
\hline 4 & 113312 & Galena, IL & 42.3994 & 90.3861 & 753.00 & $10 / 01 / 2001-09 / 30 / 2012$ \\
\hline 5 & 114355 & Illinois City Dam 16, IL & 41.4256 & 91.0094 & 550.00 & $10 / 01 / 2001-09 / 30 / 2012$ \\
\hline 6 & 114823 & La Harpe, IL & 40.5839 & 90.9686 & 690.00 & $10 / 01 / 2001-09 / 30 / 2012$ \\
\hline 7 & 116080 & New Boston Dam 17, IL & 41.1925 & 91.0578 & 548.00 & $10 / 01 / 2001-09 / 30 / 2012$ \\
\hline 8 & 117072 & Quincy Regional Airport, IL & 39.9369 & 91.1919 & 769.00 & $10 / 01 / 2001-09 / 30 / 2012$ \\
\hline 9 & 117077 & Quincy Dam 21, IL & 39.9058 & 91.4281 & 483.00 & $10 / 01 / 2001-09 / 30 / 2012$ \\
\hline 10 & 117388 & Rock Island Lock and Dam 15, IL & 41.5181 & 90.5647 & 568.00 & $10 / 01 / 2001-09 / 30 / 2012$ \\
\hline 11 & 130112 & Albia 3 NNE, IA & 41.0656 & 92.7867 & 880.00 & $10 / 01 / 2001-09 / 30 / 2012$ \\
\hline 12 & 130133 & Algona $3 \mathrm{~W}$, IA & 43.0683 & 94.3053 & $1,239.00$ & $10 / 01 / 2001-09 / 30 / 2012$ \\
\hline 13 & 130157 & Allison, IA & 42.7536 & 92.8022 & $1,048.00$ & $10 / 01 / 2001-09 / 30 / 2012$ \\
\hline 14 & 130193 & Amana, IA & 41.8083 & 91.8750 & 730.00 & $10 / 01 / 2001-09 / 30 / 2012$ \\
\hline 15 & 130197 & Ames Municipal Airport, IA & 41.9906 & 93.6189 & 955.00 & $10 / 01 / 2001-09 / 30 / 2012$ \\
\hline 16 & 130200 & Ames 8 WSW, IA & 42.0208 & 93.7742 & $1,099.00$ & $10 / 01 / 2001-09 / 30 / 2012$ \\
\hline 17 & 130203 & Ames 5 SE, IA & 41.9519 & 93.5656 & 870.00 & $10 / 01 / 2001-09 / 30 / 2012$ \\
\hline 18 & 130213 & Anamosa $1 \mathrm{WNW}$, IA & 42.1117 & 91.2933 & 805.00 & $10 / 01 / 2001-09 / 30 / 2012$ \\
\hline 19 & 130241 & Ankeny, IA & 41.7183 & 93.5742 & 940.00 & $10 / 01 / 2001-09 / 30 / 2012$ \\
\hline 20 & 130385 & Audubon, IA & 41.7069 & 94.9222 & $1,280.00$ & $10 / 01 / 2001-09 / 30 / 2012$ \\
\hline 21 & 130600 & Belle Plaine, IA & 41.8814 & 92.2764 & 810.00 & $10 / 01 / 2001-09 / 30 / 2012$ \\
\hline 22 & 130608 & Bellevue Lock and Dam 12, IA & 42.2611 & 90.4231 & 603.00 & $10 / 01 / 2001-09 / 30 / 2012$ \\
\hline 23 & 130753 & Bloomfield 1 WNW, IA & 40.7597 & 92.4394 & 812.00 & $10 / 01 / 2001-09 / 30 / 2012$ \\
\hline 24 & 130807 & Boone, IA & 42.0417 & 93.8906 & $1,051.00$ & $10 / 01 / 2001-09 / 30 / 2012$ \\
\hline 25 & 130933 & Brooklyn, IA & 41.7394 & 92.4400 & 910.00 & $10 / 01 / 2001-09 / 30 / 2012$ \\
\hline 26 & 130999 & Buckeye, IA & 42.4172 & 93.3775 & $1,150.00$ & $10 / 01 / 2001-09 / 30 / 2012$ \\
\hline 27 & 131060 & Burlington $2 \mathrm{~S}$, IA & 40.7747 & 91.1164 & 690.00 & $10 / 01 / 2001-09 / 30 / 2012$ \\
\hline 28 & 131233 & Carroll, IA & 42.0650 & 94.8500 & $1,240.00$ & $10 / 01 / 2001-09 / 30 / 2012$ \\
\hline 29 & 131257 & Cascade, IA & 42.2989 & 90.9983 & 870.00 & $10 / 01 / 2001-09 / 30 / 2012$ \\
\hline 30 & 131300 & Cedar Falls, IA & 42.5378 & 92.4431 & 763.00 & $10 / 01 / 2001-09 / 30 / 2012$ \\
\hline 31 & 131314 & Cedar Rapids Municipal Airport, IA & 41.8833 & 91.7167 & 868.00 & $10 / 01 / 2001-09 / 30 / 2012$ \\
\hline 32 & 131319 & Cedar Rapids 1, IA & 42.0500 & 91.5881 & 810.00 & $10 / 01 / 2001-09 / 30 / 2012$ \\
\hline 33 & 131394 & Chariton $1 \mathrm{E}$, IA & 41.0164 & 93.2792 & 940.00 & $10 / 01 / 2001-09 / 30 / 2012$ \\
\hline 34 & 131402 & Charles City, IA & 43.0603 & 92.6717 & 993.00 & $10 / 01 / 2001-09 / 30 / 2012$ \\
\hline 35 & 131610 & Clermont, IA & 42.9975 & 91.6583 & 840.00 & $10 / 01 / 2001-09 / 30 / 2012$ \\
\hline 36 & 131635 & Clinton 1 , IA & 41.7947 & 90.2639 & 585.00 & $10 / 01 / 2001-09 / 30 / 2012$ \\
\hline 37 & 131704 & Clutier, IA & 42.0800 & 92.4050 & 900.00 & $10 / 01 / 2001-09 / 30 / 2012$ \\
\hline 38 & 131954 & Cresco 1 NE, IA & 43.3894 & 92.0939 & $1,255.00$ & $10 / 01 / 2001-09 / 30 / 2012$ \\
\hline 39 & 132110 & Decorah, IA & 43.3042 & 91.7953 & 860.00 & $10 / 01 / 2001-09 / 30 / 2012$ \\
\hline
\end{tabular}


Table 2. National Oceanic and Atmospheric Administration's National Weather Service Cooperative Observer Program meteorological stations used in the Precipitation-Runoff Modeling System models of nine river basins in eastern lowa.—Continued

[Latitude and longitude in decimal degrees; IL, Illinois; NNE, north, northeast; IA, Iowa; W, west; WSW, west, southwest; SE, southeast; WNW, west, northwest; S, south; E, east; NE, northeast; Wsfo, weather service forecast office; N, north; ft, fort; Mt, Mount; NNW, north, northwest; SW, southwest; NW, northwest; SSW, south, southwest; MN, Minnesota; MO, Missouri; WI, Wisconsin]

\begin{tabular}{|c|c|c|c|c|c|c|}
\hline $\begin{array}{c}\text { Map } \\
\text { number } \\
\text { (fig. 4) }\end{array}$ & $\begin{array}{l}\text { Station } \\
\text { number }\end{array}$ & Meteorological station name & $\begin{array}{l}\text { Latitude } \\
\text { (north) }\end{array}$ & $\begin{array}{l}\text { Longitude } \\
\text { (west) }\end{array}$ & Elevation & Period of record used \\
\hline 40 & 132112 & Decorah 2 S, IA & 43.2833 & 91.7833 & 879.00 & $10 / 01 / 2001-09 / 30 / 2012$ \\
\hline 41 & 132203 & Des Moines International Airport, IA & 41.5339 & 93.6531 & 957.00 & $10 / 01 / 2001-09 / 30 / 2012$ \\
\hline 42 & 132205 & Des Moines 17 E, IA & 41.5561 & 93.2856 & 921.00 & $10 / 01 / 2001-09 / 30 / 2012$ \\
\hline 43 & 132209 & Des Moines Wsfo Johnston, IA & 41.7367 & 93.7236 & 959.00 & $10 / 01 / 2001-09 / 30 / 2012$ \\
\hline 44 & 132235 & De Witt, IA & 41.8108 & 90.5406 & 685.00 & $10 / 01 / 2001-09 / 30 / 2012$ \\
\hline 45 & 132299 & Donnellson, IA & 40.6458 & 91.5639 & 705.00 & $10 / 01 / 2001-09 / 30 / 2012$ \\
\hline 46 & 132311 & Dorchester, IA & 43.4706 & 91.5108 & 758.00 & $10 / 01 / 2001-09 / 30 / 2012$ \\
\hline 47 & 132364 & Dubuque Lock and Dam 11, IA & 42.5400 & 90.6461 & 620.00 & $10 / 01 / 2001-09 / 30 / 2012$ \\
\hline 48 & 132367 & Dubuque Regional Airport, IA & 42.3978 & 90.7036 & $1,056.00$ & $10 / 01 / 2001-09 / 30 / 2012$ \\
\hline 49 & 132573 & Eldora, IA & 42.3619 & 93.0989 & $1,144.00$ & $10 / 01 / 2001-09 / 30 / 2012$ \\
\hline 50 & 132603 & Elkader, IA & 42.7753 & 91.4536 & 788.00 & $10 / 01 / 2001-09 / 30 / 2012$ \\
\hline 51 & 132638 & Elma, IA & 43.2419 & 92.4433 & $1,172.00$ & $10 / 01 / 2001-09 / 30 / 2012$ \\
\hline 52 & 132724 & Estherville $2 \mathrm{~N}$, IA & 43.4036 & 94.7472 & $1,320.00$ & $10 / 01 / 2001-09 / 30 / 2012$ \\
\hline 53 & 132725 & Estherville Municipal Airport, IA & 43.4011 & 94.7472 & $1,317.00$ & $10 / 01 / 2001-09 / 30 / 2012$ \\
\hline 54 & 132789 & Fairfield, IA & 41.0211 & 91.9553 & 740.00 & $10 / 01 / 2001-09 / 30 / 2012$ \\
\hline 55 & 132864 & Fayette, IA & 42.8503 & 91.8158 & $1,130.00$ & $10 / 01 / 2001-09 / 30 / 2012$ \\
\hline 56 & 132977 & Forest City 2 NNE, IA & 43.2844 & 93.6306 & $1,300.00$ & $10 / 01 / 2001-09 / 30 / 2012$ \\
\hline 57 & 132999 & Ft Dodge 5 NNW, IA & 42.5836 & 94.2006 & $1,140.00$ & $10 / 01 / 2001-09 / 30 / 2012$ \\
\hline 58 & 133007 & Ft Madison, IA & 40.6222 & 91.3339 & 530.00 & $10 / 01 / 2001-09 / 30 / 2012$ \\
\hline 59 & 133120 & Garwin, IA & 42.0900 & 92.6756 & 912.00 & $10 / 01 / 2001-09 / 30 / 2012$ \\
\hline 60 & 133239 & Gilman, IA & 41.8781 & 92.7786 & $1,040.00$ & $10 / 01 / 2001-09 / 30 / 2012$ \\
\hline 61 & 133438 & Greenfield, IA & 41.2981 & 94.4561 & $1,340.00$ & $10 / 01 / 2001-09 / 30 / 2012$ \\
\hline 62 & 133473 & Grinnell 3 SW, IA & 41.7203 & 92.7489 & 905.00 & $10 / 01 / 2001-09 / 30 / 2012$ \\
\hline 63 & 133487 & Grundy Center, IA & 42.3647 & 92.7594 & $1,045.00$ & $10 / 01 / 2001-09 / 30 / 2012$ \\
\hline 64 & 133509 & Guthrie Center, IA & 41.6686 & 94.4972 & $1,075.00$ & $10 / 01 / 2001-09 / 30 / 2012$ \\
\hline 65 & 133517 & Guttenberg Lock and Dam 10, IA & 42.7858 & 91.0958 & 618.00 & $10 / 01 / 2001-09 / 30 / 2012$ \\
\hline 66 & 133584 & Hampton, IA & 42.7561 & 93.2011 & $1,230.00$ & $10 / 01 / 2001-09 / 30 / 2012$ \\
\hline 67 & 133960 & Hubbard, IA & 42.3008 & 93.3008 & $1,089.00$ & $10 / 01 / 2001-09 / 30 / 2012$ \\
\hline 68 & 134063 & Indianola, IA & 41.3656 & 93.6481 & 942.00 & $10 / 01 / 2001-09 / 30 / 2012$ \\
\hline 69 & 134094 & Ionia $2 \mathrm{~W}$, IA & 43.0336 & 92.5017 & $1,019.00$ & $10 / 01 / 2001-09 / 30 / 2012$ \\
\hline 70 & 134101 & Iowa City, IA & 41.6092 & 91.5050 & 640.00 & $10 / 01 / 2001-09 / 30 / 2012$ \\
\hline 71 & 134106 & Iowa City Municipal Airport, IA & 41.6328 & 91.5431 & 650.00 & $10 / 01 / 2001-09 / 30 / 2012$ \\
\hline 72 & 134142 & Iowa Falls, IA & 42.5189 & 93.2536 & $1,130.00$ & $10 / 01 / 2001-09 / 30 / 2012$ \\
\hline 73 & 134228 & Jefferson, IA & 42.0347 & 94.4114 & $1,055.00$ & $10 / 01 / 2001-09 / 30 / 2012$ \\
\hline 74 & 134244 & Jewell, IA & 42.3008 & 93.6389 & $1,060.00$ & $10 / 01 / 2001-09 / 30 / 2012$ \\
\hline 75 & 134308 & Kanawha, IA & 42.9311 & 93.7933 & $1,185.00$ & $10 / 01 / 2001-09 / 30 / 2012$ \\
\hline 76 & 134381 & Keokuk Lock and Dam 19, IA & 40.3967 & 91.3750 & 527.00 & $10 / 01 / 2001-09 / 30 / 2012$ \\
\hline 77 & 134389 & Keosauqua, IA & 40.7275 & 91.9683 & 592.00 & $10 / 01 / 2001-09 / 30 / 2012$ \\
\hline 78 & 134502 & Knoxville, IA & 41.3247 & 93.1008 & 915.00 & $10 / 01 / 2001-09 / 30 / 2012$ \\
\hline
\end{tabular}


Table 2. National Oceanic and Atmospheric Administration's National Weather Service Cooperative Observer Program meteorological stations used in the Precipitation-Runoff Modeling System models of nine river basins in eastern lowa.-Continued

[Latitude and longitude in decimal degrees; IL, Illinois; NNE, north, northeast; IA, Iowa; W, west; WSW, west, southwest; SE, southeast; WNW, west, northwest; S, south; E, east; NE, northeast; Wsfo, weather service forecast office; N, north; ft, fort; Mt, Mount; NNW, north, northwest; SW, southwest; NW, northwest; SSW, south, southwest; MN, Minnesota; MO, Missouri; WI, Wisconsin]

\begin{tabular}{|c|c|c|c|c|c|c|}
\hline $\begin{array}{c}\text { Map } \\
\text { number } \\
\text { (fig. 4) }\end{array}$ & $\begin{array}{l}\text { Station } \\
\text { number }\end{array}$ & Meteorological station name & $\begin{array}{l}\text { Latitude } \\
\text { (north) }\end{array}$ & $\begin{array}{l}\text { Longitude } \\
\text { (west) }\end{array}$ & Elevation & Period of record used \\
\hline 79 & 134557 & Lake Mills, IA & 43.4178 & 93.5347 & $1,260.00$ & $10 / 01 / 2001-09 / 30 / 2012$ \\
\hline 80 & 134705 & Le Claire Lock and Dam 14, IA & 41.5747 & 90.4006 & 577.00 & $10 / 01 / 2001-09 / 30 / 2012$ \\
\hline 81 & 134963 & Lowden, IA & 41.8564 & 90.9300 & 715.00 & $10 / 01 / 2001-09 / 30 / 2012$ \\
\hline 82 & 135086 & Manchester 2, IA & 42.4733 & 91.4517 & 990.00 & $10 / 01 / 2001-09 / 30 / 2012$ \\
\hline 83 & 135131 & Maquoketa, IA & 42.0494 & 90.7489 & 762.00 & $10 / 01 / 2001-09 / 30 / 2012$ \\
\hline 84 & 135198 & Marshalltown, IA & 42.0647 & 92.9244 & 870.00 & $10 / 01 / 2001-09 / 30 / 2012$ \\
\hline 85 & 135199 & Marshalltown Municipal Airport, IA & 42.1106 & 92.9161 & 974.00 & $10 / 01 / 2001-09 / 30 / 2012$ \\
\hline 86 & 135230 & Mason City, IA & 43.1631 & 93.1953 & $1,105.00$ & $10 / 01 / 2001-09 / 30 / 2012$ \\
\hline 87 & 135232 & Mason City 1, IA & 43.1533 & 93.1981 & $1,097.00$ & $10 / 01 / 2001-09 / 30 / 2012$ \\
\hline 88 & 135235 & Mason City Municipal Airport, IA & 43.1544 & 93.3269 & $1,225.00$ & $10 / 01 / 2001-09 / 30 / 2012$ \\
\hline 89 & 135493 & Milford 4 NW, IA & 43.3828 & 95.1842 & $1,402.00$ & $10 / 01 / 2001-09 / 30 / 2012$ \\
\hline 90 & 135622 & Monmouth 4 SW, IA & 42.0500 & 90.9167 & 869.00 & $10 / 01 / 2001-09 / 30 / 2012$ \\
\hline 91 & 135650 & Montezuma 1 W, IA & 41.5836 & 92.5497 & 965.00 & $10 / 01 / 2001-09 / 30 / 2012$ \\
\hline 92 & 135796 & Mt Pleasant 1 SSW, IA & 40.9486 & 91.5647 & 730.00 & $10 / 01 / 2001-09 / 30 / 2012$ \\
\hline 93 & 135837 & Muscatine, IA & 41.4075 & 91.0728 & 549.00 & $10 / 01 / 2001-09 / 30 / 2012$ \\
\hline 94 & 135844 & Muscatine $2 \mathrm{~N}$, IA & 41.4714 & 91.0464 & 680.00 & $10 / 01 / 2001-09 / 30 / 2012$ \\
\hline 95 & 135952 & New Hampton, IA & 43.0453 & 92.3122 & $1,148.00$ & $10 / 01 / 2001-09 / 30 / 2012$ \\
\hline 96 & 135992 & Newton, IA & 41.7117 & 93.0297 & 960.00 & $10 / 01 / 2001-09 / 30 / 2012$ \\
\hline 97 & 136103 & Northwood, IA & 43.4386 & 93.2253 & $1,190.00$ & $10 / 01 / 2001-09 / 30 / 2012$ \\
\hline 98 & 136200 & Oelwein $2 \mathrm{~S}$, IA & 42.6467 & 91.9131 & $1,010.00$ & $10 / 01 / 2001-09 / 30 / 2012$ \\
\hline 99 & 136305 & Osage, IA & 43.2794 & 92.8106 & $1,170.00$ & $10 / 01 / 2001-09 / 30 / 2012$ \\
\hline 100 & 136316 & Osceola, IA & 41.0194 & 93.7503 & $1,028.00$ & $10 / 01 / 2001-09 / 30 / 2012$ \\
\hline 101 & 136327 & Oskaloosa, IA & 41.3214 & 92.6467 & 830.00 & $10 / 01 / 2001-09 / 30 / 2012$ \\
\hline 102 & 136389 & Ottumwa Industrial Airport, IA & 41.1078 & 92.4467 & 842.00 & $10 / 01 / 2001-09 / 30 / 2012$ \\
\hline 103 & 136527 & Pella $1 \mathrm{~S}$, IA & 41.3761 & 92.9203 & 780.00 & $10 / 01 / 2001-09 / 30 / 2012$ \\
\hline 104 & 136566 & Perry, IA & 41.8394 & 94.1106 & 965.00 & $10 / 01 / 2001-09 / 30 / 2012$ \\
\hline 105 & 136719 & Pocahontas, IA & 42.7292 & 94.6614 & $1,212.00$ & $10 / 01 / 2001-09 / 30 / 2012$ \\
\hline 106 & 136755 & Popejoy 1S, IA & 42.5864 & 93.4364 & $1,175.00$ & $10 / 01 / 2001-09 / 30 / 2012$ \\
\hline 107 & 136766 & Postville, IA & 43.0900 & 91.5581 & $1,165.00$ & $10 / 01 / 2001-09 / 30 / 2012$ \\
\hline 108 & 137161 & Rockwell City, IA & 42.3969 & 94.6292 & $1,195.00$ & $10 / 01 / 2001-09 / 30 / 2012$ \\
\hline 109 & 137312 & Sac City, IA & 42.4194 & 94.9761 & $1,210.00$ & $10 / 01 / 2001-09 / 30 / 2012$ \\
\hline 110 & 137678 & Sigourney, IA & 41.3328 & 92.1975 & 800.00 & $10 / 01 / 2001-09 / 30 / 2012$ \\
\hline 111 & 137726 & Sioux Rapids 4 E, IA & 42.8931 & 95.0653 & $1,420.00$ & $10 / 01 / 2001-09 / 30 / 2012$ \\
\hline 112 & 137859 & Spirit Lake, IA & 43.4231 & 95.1394 & $1,420.00$ & $10 / 01 / 2001-09 / 30 / 2012$ \\
\hline 113 & 137932 & Steamboat Rock, IA & 42.4069 & 93.0697 & 980.00 & $10 / 01 / 2001-09 / 30 / 2012$ \\
\hline 114 & 137979 & Storm Lake 2 E, IA & 42.6347 & 95.1694 & $1,425.00$ & $10 / 01 / 2001-09 / 30 / 2012$ \\
\hline 115 & 138026 & Swea City, IA & 43.4022 & 94.3831 & $1,239.00$ & $10 / 01 / 2001-09 / 30 / 2012$ \\
\hline 116 & 138062 & Swisher, IA & 41.8497 & 91.6764 & 790.00 & $10 / 01 / 2001-09 / 30 / 2012$ \\
\hline 117 & 138296 & Toledo 3 N, IA & 42.0356 & 92.5806 & 949.00 & $10 / 01 / 2001-09 / 30 / 2012$ \\
\hline
\end{tabular}


Table 2. National Oceanic and Atmospheric Administration's National Weather Service Cooperative Observer Program meteorological stations used in the Precipitation-Runoff Modeling System models of nine river basins in eastern lowa.—Continued

[Latitude and longitude in decimal degrees; IL, Illinois; NNE, north, northeast; IA, Iowa; W, west; WSW, west, southwest; SE, southeast; WNW, west, northwest; S, south; E, east; NE, northeast; Wsfo, weather service forecast office; N, north; ft, fort; Mt, Mount; NNW, north, northwest; SW, southwest; NW, northwest; SSW, south, southwest; MN, Minnesota; MO, Missouri; WI, Wisconsin]

\begin{tabular}{|c|c|c|c|c|c|c|}
\hline $\begin{array}{c}\text { Map } \\
\text { number } \\
\text { (fig. 4) }\end{array}$ & $\begin{array}{l}\text { Station } \\
\text { number }\end{array}$ & Meteorological station name & $\begin{array}{l}\text { Latitude } \\
\text { (north) }\end{array}$ & $\begin{array}{l}\text { Longitude } \\
\text { (west) }\end{array}$ & Elevation & Period of record used \\
\hline 118 & 138339 & Tripoli, IA & 42.8125 & 92.2575 & 960.00 & $10 / 01 / 2001-09 / 30 / 2012$ \\
\hline 119 & 138568 & Vinton, IA & 42.1703 & 92.0078 & 850.00 & $10 / 01 / 2001-09 / 30 / 2012$ \\
\hline 120 & 138632 & Walford 2 SE, IA & 41.8625 & 91.8025 & 790.00 & $10 / 01 / 2001-09 / 30 / 2012$ \\
\hline 121 & 138668 & Wapello, IA & 41.1761 & 91.1922 & 590.00 & $10 / 01 / 2001-09 / 30 / 2012$ \\
\hline 122 & 138688 & Washington, IA & 41.2825 & 91.7078 & 687.00 & $10 / 01 / 2001-09 / 30 / 2012$ \\
\hline 123 & 138706 & Waterloo Municipal Airport, IA & 42.5544 & 92.4011 & 868.00 & $10 / 01 / 2001-09 / 30 / 2012$ \\
\hline 124 & 138742 & Waucoma 3 SE, IA & 43.0533 & 92.0372 & $1,045.00$ & $10 / 01 / 2001-09 / 30 / 2012$ \\
\hline 125 & 138755 & Waukon, IA & 43.2742 & 91.4711 & $1,275.00$ & $10 / 01 / 2001-09 / 30 / 2012$ \\
\hline 126 & 138806 & Webster City, IA & 42.4686 & 93.7972 & $1,170.00$ & $10 / 01 / 2001-09 / 30 / 2012$ \\
\hline 127 & 139067 & Williamsburg, IA & 41.6403 & 91.9783 & 810.00 & $10 / 01 / 2001-09 / 30 / 2012$ \\
\hline 128 & 139132 & Winterset 2 NNW, IA & 41.3561 & 94.0128 & $1,040.00$ & $10 / 01 / 2001-09 / 30 / 2012$ \\
\hline 129 & 139750 & Zearing, IA & 42.1669 & 93.3097 & $1,116.00$ & $10 / 01 / 2001-09 / 30 / 2012$ \\
\hline 130 & 210075 & Albert Lea 3 SE, MN & 43.6064 & 93.3019 & $1,230.00$ & $10 / 01 / 2001-09 / 30 / 2012$ \\
\hline 131 & 210355 & $\begin{array}{l}\text { Austin Waste Water Treatment } \\
\text { Facility, MN }\end{array}$ & 43.6542 & 92.9739 & $1,199.00$ & $10 / 01 / 2001-09 / 30 / 2012$ \\
\hline 132 & 210981 & Bricelyn, MN & 43.5439 & 93.8422 & $1,170.00$ & $10 / 01 / 2001-09 / 30 / 2012$ \\
\hline 133 & 211198 & Caledonia, MN & 43.6308 & 91.5028 & $1,166.00$ & $10 / 01 / 2001-09 / 30 / 2012$ \\
\hline 134 & 212698 & Fairmont, MN & 43.6447 & 94.4656 & $1,187.00$ & $10 / 01 / 2001-09 / 30 / 2012$ \\
\hline 135 & 213290 & Grand Meadow, MN & 43.7047 & 92.5644 & $1,350.00$ & $10 / 01 / 2001-09 / 30 / 2012$ \\
\hline 136 & 213520 & Harmony, MN & 43.5458 & 92.0122 & $1,350.00$ & $10 / 01 / 2001-09 / 30 / 2012$ \\
\hline 137 & 214453 & Lakefield, MN & 43.7022 & 95.1519 & $1,530.00$ & $10 / 01 / 2001-09 / 30 / 2012$ \\
\hline 138 & 214534 & Lake Wilson, MN & 43.9981 & 95.9572 & $1,650.00$ & $10 / 01 / 2001-09 / 30 / 2012$ \\
\hline 139 & 214563 & Lanesboro, MN & 43.7203 & 91.9717 & 955.00 & $10 / 01 / 2001-09 / 30 / 2012$ \\
\hline 140 & 216654 & Preston, MN & 43.6725 & 92.0747 & 930.00 & $10 / 01 / 2001-09 / 30 / 2012$ \\
\hline 141 & 218323 & Tracy, MN & 44.2394 & 95.6308 & $1,403.00$ & $10 / 01 / 2001-09 / 30 / 2012$ \\
\hline 142 & 219033 & Windom, MN & 43.8575 & 95.1167 & $1,375.00$ & $10 / 01 / 2001-09 / 30 / 2012$ \\
\hline 143 & 219170 & Worthington 2 NNE, MN & 43.6450 & 95.5803 & $1,570.00$ & $10 / 01 / 2001-09 / 30 / 2012$ \\
\hline 144 & 231275 & Canton Lock and Dam 20, MO & 40.1433 & 91.5158 & 490.00 & $10 / 01 / 2001-09 / 30 / 2012$ \\
\hline 145 & 232482 & Edina, MO & 40.1636 & 92.1658 & 808.00 & $10 / 01 / 2001-09 / 30 / 2012$ \\
\hline 146 & 234544 & Kirksville, MO & 40.2058 & 92.5747 & 970.00 & $10 / 01 / 2001-09 / 30 / 2012$ \\
\hline 147 & 235492 & Memphis, MO & 40.4575 & 92.1822 & 770.00 & $10 / 01 / 2001-09 / 30 / 2012$ \\
\hline 148 & 238051 & Steffenville, MO & 39.9714 & 91.8872 & 690.00 & $10 / 01 / 2001-09 / 30 / 2012$ \\
\hline 149 & 473038 & Genoa Dam 8, WI & 43.5706 & 91.2294 & 639.00 & $10 / 01 / 2001-09 / 30 / 2012$ \\
\hline 150 & 474546 & Lancaster 4 WSW, WI & 42.8278 & 90.7889 & $1,040.00$ & $10 / 01 / 2001-09 / 30 / 2012$ \\
\hline 151 & 474937 & Lynxville Dam 9, WI & 43.2117 & 91.0986 & 633.00 & $10 / 01 / 2001-09 / 30 / 2012$ \\
\hline 152 & 476646 & Platteville, WI & 42.7489 & 90.4656 & 990.00 & $10 / 01 / 2001-09 / 30 / 2012$ \\
\hline 153 & 476827 & Prairie Du Chien, WI & 43.0514 & 91.1350 & 658.00 & $10 / 01 / 2001-09 / 30 / 2012$ \\
\hline 154 & 478164 & Steuben 4 SE, WI & 43.1342 & 90.8372 & $1,015.00$ & $10 / 01 / 2001-09 / 30 / 2012$ \\
\hline 155 & 478827 & Viroqua, WI & 43.5594 & 90.8761 & $1,255.00$ & $10 / 01 / 2001-09 / 30 / 2012$ \\
\hline
\end{tabular}


Table 3. Nash-Sutcliffe efficiency, coefficient of determination, percent bias, and root mean square error-observation standard deviation ratio statistic values at U.S. Geological Survey streamflow-gaging stations used for calibration or validation periods in the Precipitation-Runoff Modeling System models of nine river basins in eastern lowa.

[Red indicates that statistic value below satisfactory rating level. USGS, U.S. Geological Survey; NSE, Nash-Sutcliffe efficiency; $R^{2}$, coefficient of determination; PBIAS, percent bias; RSR, root mean square error-observation standard deviation ratio; IA, Iowa; C, calibration location; Cr, Creek; V, validation location; NE, Northeast; MN, Minnesota; DS, downstream; MO, Missouri]

\begin{tabular}{|c|c|c|c|c|c|c|c|}
\hline $\begin{array}{c}\text { Map } \\
\text { number } \\
\text { (fig. 2) }\end{array}$ & $\begin{array}{c}\text { USGS } \\
\text { station } \\
\text { number }\end{array}$ & USGS station name & Type & NSE & $R^{2}$ & PBIAS & RSR \\
\hline \multicolumn{8}{|c|}{ Upper lowa River Basin } \\
\hline 1 & 05387440 & Upper Iowa River at Bluffton, IA & $\mathrm{C}$ & 0.79 & 0.79 & 1.25 & 0.46 \\
\hline 2 & 05387500 & Upper Iowa River at Decorah, IA & $\mathrm{C}$ & 0.84 & 0.85 & 5.23 & 0.40 \\
\hline 3 & 05388250 & Upper Iowa River near Dorchester, IA & $\mathrm{C}$ & 0.88 & 0.88 & -2.68 & 0.35 \\
\hline 4 & 05389000 & Yellow River near Ion, IA & $\mathrm{C}$ & 0.68 & 0.71 & -7.74 & 0.56 \\
\hline \multicolumn{8}{|c|}{ Turkey River Basin } \\
\hline 5 & 05411600 & Turkey River at Spillville, IA & $\mathrm{C}$ & 0.49 & 0.52 & -5.88 & 0.71 \\
\hline 6 & 05411850 & Turkey River near Eldorado, IA & $\mathrm{C}$ & 0.51 & 0.51 & -9.04 & 0.70 \\
\hline 10 & 05412500 & Turkey River at Garber, IA & $\mathrm{C}$ & 0.66 & 0.66 & -8.42 & 0.59 \\
\hline \multicolumn{8}{|c|}{ Maquoketa River Basin } \\
\hline 11 & 05416900 & Maquoketa River at Manchester, IA & $\mathrm{C}$ & 0.50 & 0.51 & 23.89 & 0.71 \\
\hline 12 & 05418400 & North Fork Maquoketa River near Fulton, IA & $\mathrm{C}$ & 0.55 & 0.58 & 11.15 & 0.67 \\
\hline 13 & 05418500 & Maquoketa River near Maquoketa, IA & $\mathrm{C}$ & 0.65 & 0.68 & 16.76 & 0.59 \\
\hline \multicolumn{8}{|c|}{ Wapsipinicon River Basin } \\
\hline 14 & 05420560 & Wapsipinicon River near Elma, IA & $\mathrm{C}$ & 0.43 & 0.44 & -17.54 & 0.75 \\
\hline 15 & 05420680 & Wapsipinicon River near Tripoli, IA & $\mathrm{C}$ & 0.66 & 0.70 & -24.15 & 0.58 \\
\hline 16 & 05421000 & Wapsipinicon River at Independence, IA & $\mathrm{V}$ & 0.70 & 0.72 & -12.93 & 0.55 \\
\hline 22 & 05451210 & South Fork Iowa River NE of New Providence, IA & $\mathrm{C}$ & 0.62 & 0.65 & 30.26 & 0.61 \\
\hline 23 & 05451500 & Iowa River at Marshalltown, IA & $\mathrm{C}$ & 0.65 & 0.68 & 23.52 & 0.59 \\
\hline 24 & 05451700 & Timber Creek near Marshalltown, IA & $\mathrm{C}$ & 0.45 & 0.46 & 14.66 & 0.74 \\
\hline 25 & 05451900 & Richland Creek near Haven, IA & $\mathrm{C}$ & 0.50 & 0.52 & 20.46 & 0.70 \\
\hline 26 & 05452000 & Salt Creek near Elberon, IA & $\mathrm{C}$ & 0.65 & 0.66 & 16.53 & 0.59 \\
\hline 27 & 05452200 & Walnut Creek near Hartwick, IA & $\mathrm{C}$ & 0.29 & 0.47 & 1.29 & 0.84 \\
\hline 28 & 05453000 & Big Bear Creek at Ladora, IA & $\mathrm{C}$ & 0.54 & 0.55 & 17.65 & 0.68 \\
\hline 29 & 05453100 & Iowa River at Marengo, IA & $\mathrm{C}$ & 0.73 & 0.76 & 20.90 & 0.52 \\
\hline 31 & 05454000 & Rapid Creek near Iowa City, IA & $\mathrm{C}$ & 0.42 & 0.48 & 21.18 & 0.76 \\
\hline 32 & 05454090 & Muddy Creek at Coralville, IA & $\mathrm{V}$ & 0.50 & 0.43 & 9.51 & 0.71 \\
\hline 33 & 05454220 & Clear Creek near Oxford, IA & $\mathrm{C}$ & 0.54 & 0.56 & 20.03 & 0.68 \\
\hline
\end{tabular}


Table 3. Nash-Sutcliffe efficiency, coefficient of determination, percent bias, and root mean square error-observation standard deviation ratio statistic values at U.S. Geological Survey streamflow-gaging stations used for calibration or validation periods in the Precipitation-Runoff Modeling System models of nine river basins in eastern lowa._Continued

[Red indicates that statistic value below satisfactory rating level. USGS, U.S. Geological Survey; NSE, Nash-Sutcliffe efficiency; $R^{2}$, coefficient of determination; PBIAS, percent bias; RSR, root mean square error-observation standard deviation ratio; IA, Iowa; C, calibration location; Cr, Creek; V, validation location; NE, Northeast; MN, Minnesota; DS, downstream; MO, Missouri]

\begin{tabular}{|c|c|c|c|c|c|c|c|}
\hline $\begin{array}{c}\text { Map } \\
\text { number } \\
\text { (fig. 2) }\end{array}$ & $\begin{array}{c}\text { USGS } \\
\text { station } \\
\text { number }\end{array}$ & USGS station name & Type & NSE & $R^{2}$ & PBIAS & RSR \\
\hline \multicolumn{8}{|c|}{ lowa River Basin-Continued } \\
\hline 34 & 05454300 & Clear Creek near Coralville, IA & $\mathrm{C}$ & 0.60 & 0.62 & 21.99 & 0.63 \\
\hline 35 & 05454500 & Iowa River at Iowa City, IA & $\mathrm{C}$ & 0.99 & 1.00 & 1.56 & 0.08 \\
\hline 36 & 05455100 & Old Mans Creek near Iowa City, IA & $\mathrm{C}$ & 0.56 & 0.58 & 17.97 & 0.66 \\
\hline 38 & 05455700 & Iowa River near Lone Tree, IA & $\mathrm{C}$ & 0.92 & 0.92 & 5.10 & 0.28 \\
\hline 39 & 05457000 & Cedar River near Austin, MN & $\mathrm{C}$ & 0.39 & 0.42 & 14.97 & 0.78 \\
\hline 40 & 05457700 & Cedar River at Charles City, IA & $\mathrm{C}$ & 0.63 & 0.66 & 14.52 & 0.61 \\
\hline 41 & 05458000 & Little Cedar River near Ionia, IA & $\mathrm{C}$ & 0.70 & 0.70 & -3.57 & 0.55 \\
\hline 45 & 05459500 & Winnebago River at Mason City, IA & $\mathrm{C}$ & 0.53 & 0.60 & 17.06 & 0.69 \\
\hline 46 & 05462000 & Shell Rock River at Shell Rock, IA & $\mathrm{C}$ & 0.65 & 0.68 & 16.34 & 0.59 \\
\hline 47 & 05463000 & Beaver Creek at New Hartford, IA & $\mathrm{C}$ & 0.69 & 0.73 & 26.88 & 0.55 \\
\hline 48 & 05463500 & Black Hawk Creek at Hudson, IA & $\mathrm{C}$ & 0.59 & 0.62 & 31.82 & 0.64 \\
\hline 49 & 05464000 & Cedar River at Waterloo, IA & $\mathrm{C}$ & 0.79 & 0.82 & 21.84 & 0.46 \\
\hline 50 & 05464220 & Wolf Creek near Dysart, IA & $\mathrm{C}$ & 0.56 & 0.59 & 30.32 & 0.66 \\
\hline 51 & 05464500 & Cedar River at Cedar Rapids, IA & $\mathrm{V}$ & 0.77 & 0.79 & 17.26 & 0.48 \\
\hline 52 & 05465000 & Cedar River near Conesville, IA & $\mathrm{V}$ & 0.67 & 0.70 & 17.56 & 0.58 \\
\hline 53 & 05465500 & Iowa River at Wapello, IA & $\mathrm{V}$ & 0.74 & 0.77 & 11.53 & 0.51 \\
\hline 59 & 05471500 & South Skunk River near Oskaloosa, IA & $\mathrm{C}$ & 0.50 & 0.63 & 0.89 & 0.70 \\
\hline 60 & 05472500 & North Skunk River near Sigourney, IA & $\mathrm{C}$ & 0.68 & 0.70 & -2.61 & 0.57 \\
\hline 61 & 05473400 & Cedar Creek near Oakland Mills, IA & $\mathrm{C}$ & 0.68 & 0.71 & 1.03 & 0.57 \\
\hline 62 & 05473450 & Big Creek North of Mount Pleasant, IA & $\mathrm{C}$ & 0.57 & 0.60 & 19.07 & 0.66 \\
\hline 63 & 05474000 & Skunk River at Augusta, IA & $\mathrm{C}$ & 0.82 & 0.82 & -3.39 & 0.42 \\
\hline \multicolumn{8}{|c|}{ Des Moines River Basin } \\
\hline 64 & 05476000 & Des Moines River at Jackson, MN & $\mathrm{C}$ & 0.50 & 0.58 & -4.81 & 0.71 \\
\hline 65 & 05476750 & Des Moines River at Humboldt, IA & $\mathrm{C}$ & 0.64 & 0.65 & 12.93 & 0.60 \\
\hline 66 & 05479000 & East Fork Des Moines River at Dakota City, IA & $\mathrm{C}$ & 0.49 & 0.63 & 1.35 & 0.72 \\
\hline 67 & 05480500 & Des Moines River at Fort Dodge, IA & $\mathrm{C}$ & 0.69 & 0.71 & 7.93 & 0.55 \\
\hline 68 & 05481000 & Boone River near Webster City, IA & $\mathrm{C}$ & 0.61 & 0.65 & 24.13 & 0.62 \\
\hline
\end{tabular}


Table 3. Nash-Sutcliffe efficiency, coefficient of determination, percent bias, and root mean square error-observation standard deviation ratio statistic values at U.S. Geological Survey streamflow-gaging stations used for calibration or validation periods in the Precipitation-Runoff Modeling System models of nine river basins in eastern lowa.-Continued

[Red indicates that statistic value below satisfactory rating level. USGS, U.S. Geological Survey; NSE, Nash-Sutcliffe efficiency; $R^{2}$, coefficient of determination; PBIAS, percent bias; RSR, root mean square error-observation standard deviation ratio; IA, Iowa; C, calibration location; Cr, Creek; V, validation location; NE, Northeast; MN, Minnesota; DS, downstream; MO, Missouri]

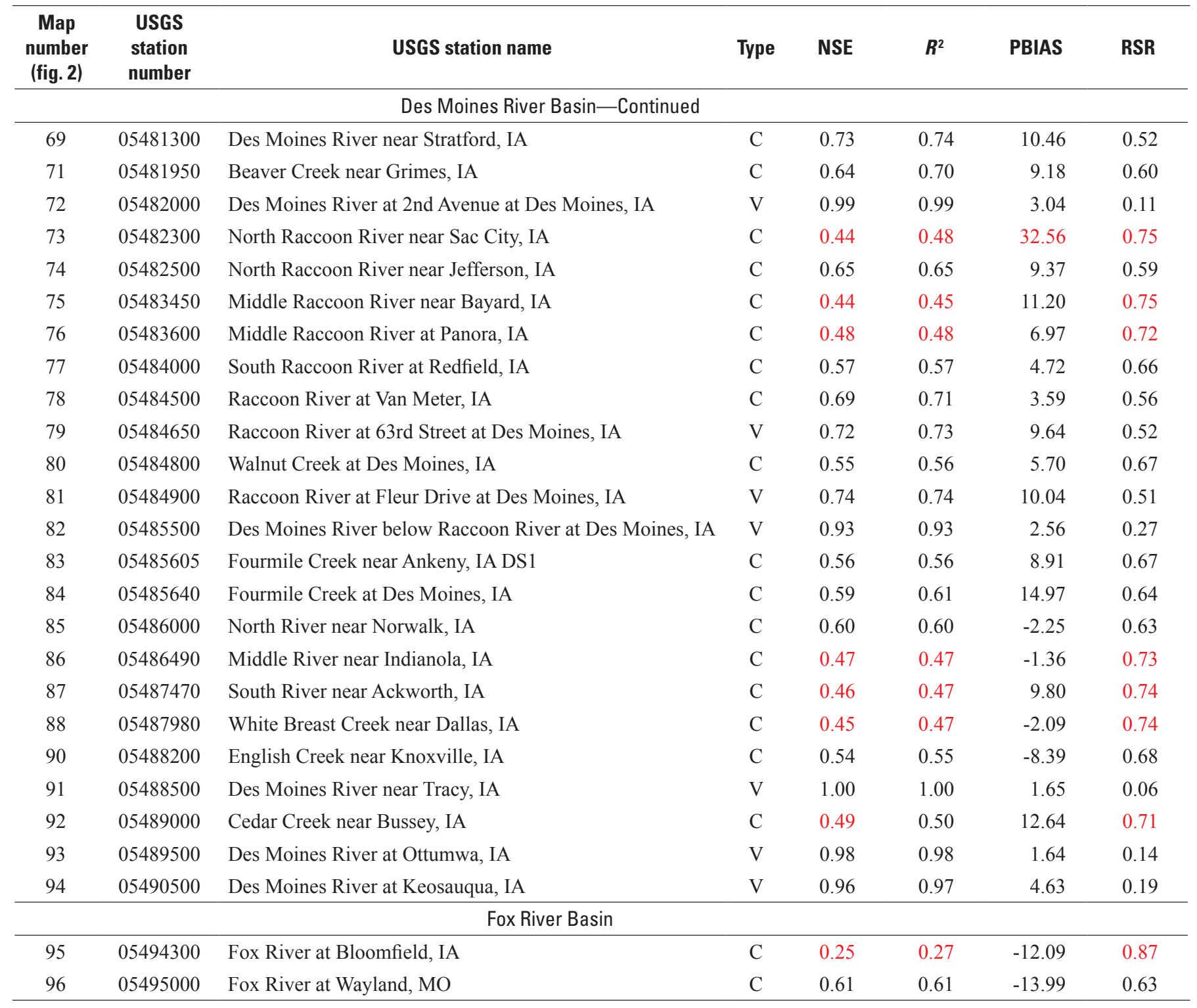


Table 4. Calibrated parameters and Let Us Calibrate (Luca) calibration steps for the Precipitation-Runoff Modeling System models of nine river basins in eastern lowa.

[PRMS, Precipitation-Runoff Modeling System; ET, evapotranspiration; nmonth, 12 months; one, one basin-wide value; NRMSE; normalized root mean square error; nhru, number of hydrologic response units; nssr, number of subsurface reservoirs equal to nhru; HRU, hydrologic response unit; ngw, number of groundwater reservoirs equal to nhru; nseg, number of model segments]

\begin{tabular}{|c|c|c|c|c|c|}
\hline $\begin{array}{c}\text { Calibration } \\
\text { dataset }\end{array}$ & Objective function & $\begin{array}{c}\text { PRMS } \\
\text { parameter }\end{array}$ & Dimensions & Range & Parameter description \\
\hline \multicolumn{6}{|c|}{ Calibration step 1} \\
\hline \multirow{2}{*}{$\begin{array}{l}\text { Solar radiation } \\
\text { and potential } \\
\text { ET }\end{array}$} & 1. Mean monthly & dday_slope & nmonth & $0.2-0.9$ & $\begin{array}{l}\text { Monthly (January to December) slope in degree- } \\
\text { day equation. }\end{array}$ \\
\hline & & jh_coef & nmonth & $0.005-0.09$ & $\begin{array}{l}\text { Monthly (January to December) air temperature } \\
\text { coefficient used in Jensen-Haise potential ET } \\
\text { calculations. }\end{array}$ \\
\hline \multicolumn{6}{|c|}{ Calibration step 2} \\
\hline Water balance & NRMSE: & adjust_rain & nmonth & $0-2.0$ & Precipitation adjustment factor for rain days. \\
\hline \multirow[t]{6}{*}{ Daily flow } & NRMSE: & adjmix_rain & nmonth & $0.6-1.4$ & $\begin{array}{l}\text { Factor to adjust proportion in mixed rain/snow } \\
\text { event. }\end{array}$ \\
\hline & 1. Daily & cecn_coef & nmonth & $0.6-1.4$ & Convection condensation energy coefficient. \\
\hline & 2. Monthly mean & freeh2o_cap & one & $0.01-0.2$ & Free-water holding capacity of the snowpack. \\
\hline & & potet_sublim & one & $0.1-0.75$ & $\begin{array}{l}\text { Fraction of potential ET that is sublimated from } \\
\text { snow surface. }\end{array}$ \\
\hline & & slowcoef_lin ${ }^{1}$ & nhru & $0.0001-0.05$ & Linerar subsurface reservoir routing coefficient. \\
\hline & & soil_moist_max ${ }^{1}$ & nssr & $2-10$ & $\begin{array}{l}\text { Maximum available water holding capacity of soil } \\
\text { profile. }\end{array}$ \\
\hline \multicolumn{6}{|c|}{ Calibration step 4} \\
\hline \multirow[t]{4}{*}{ Daily flow } & NRMSE: & fastcoef_lin ${ }^{1}$ & nhru & $0.0001-0.8$ & Linear preferential-flow routing coeficient. \\
\hline & 1. Daily high & pref_flow_den ${ }^{1}$ & nhru & $0-.1$ & Preferential-flow pore density. \\
\hline & 2. Monthly high & sat_threshold ${ }^{1}$ & nhru & $1-15$ & $\begin{array}{l}\text { Soil saturation threshold, above field-capacity } \\
\text { threshold. }\end{array}$ \\
\hline & & smidx_coef ${ }^{1}$ & nhru & $0.0001-0.8$ & $\begin{array}{l}\text { Coefficient in nonlinear surface runoff contribut- } \\
\text { ing area algorithm. }\end{array}$ \\
\hline \multicolumn{6}{|c|}{ Calibration step 5} \\
\hline \multirow[t]{3}{*}{ Daily flow } & NRMSE: & gwflow_coef $^{1}$ & ngw & $0.001-0.89$ & Groundwater routing coefficient. \\
\hline & $\begin{array}{l}\text { 1. Daily low } \\
\text { 2. Monthly low }\end{array}$ & soil2gw_max ${ }^{1}$ & nhru & $0-0.5$ & $\begin{array}{l}\text { Maximum value for lower zone excess to ground- } \\
\text { water reservoir. }\end{array}$ \\
\hline & & ssr2gw_rate ${ }^{1}$ & nssr & $0.05-0.8$ & $\begin{array}{l}\text { Coefficient to route water from subsurface reser- } \\
\text { voir to groundwater reservoir. }\end{array}$ \\
\hline
\end{tabular}


Table 4. Calibrated parameters and Let Us Calibrate (Luca) calibration steps for the Precipitation-Runoff Modeling System models of nine river basins in eastern lowa.-Continued

[PRMS, Precipitation-Runoff Modeling System; ET, evapotranspiration; nmonth, 12 months; one, one basin-wide value; NRMSE; normalized root mean square error; nhru, number of hydrologic response units; nssr, number of subsurface reservoirs equal to nhru; HRU, hydrologic response unit; ngw, number of groundwater reservoirs equal to nhru; nseg, number of model segments]

\begin{tabular}{llcccc}
\hline $\begin{array}{c}\text { Calibration } \\
\text { dataset }\end{array}$ & Objective function & $\begin{array}{c}\text { PRMS } \\
\text { parameter }\end{array}$ & Dimensions & Range & Parameter description \\
\hline Daily flow & NRMSE: & Calibration step 6 & \\
& 1. Daily & K_coef ${ }^{1}$ & nseg & $1-24$ & Muskingum storage coefficient. \\
& slowcoef_sq & nhru & $0-1$ & $\begin{array}{c}\text { Nonlinerar subsurface reservoir routing coef- } \\
\text { ficient. }\end{array}$ \\
& & & & Nonlinear preferential-flow routing coeficient. \\
\hline
\end{tabular}

${ }^{1}$ Parameter calibrated in both basin-wide and subbasin calibration.

counterparts (Gupta and others, 1999). A PBIAS value of 0.0 indicates ideal performance, whereas positive values indicate underestimation bias and negative values indicate overestimation bias (Moriasi and others, 2007). Model performance for streamflow is considered "very good" if the PBIAS is between 0 and plus or minus (+/-) 10 percent, "good" if the PBIAS is between $+/-10$ and $+/-15$ percent, "satisfactory" if the PBIAS is between $+/-15$ and $+/-25$ percent, and "unsatisfactory" if the PBIAS is $+/-25$ percent and greater (Moraisi and others, 2007).

The RSR was developed to use the standard deviation of observations to qualify what is considered a low root mean square error for model performance (Singh and others, 2004). The RSR incorporates the benefits of error index statistics and includes a normalization/scaling factor. The RSR ranges from 0 (optimal value) to a large positive value (poor fit) (Singh and others, 2004). The lower the RSR value, the better the model simulation performance. If RSR is between 0 and 0.5 then performance is "very good," if RSR is between 0.5 and 0.6 then performance is "good," RSR between 0.6 and 0.7 is "satisfactory," and RSR greater than 0.7 is "unsatisfactory" (Moraisi and others, 2007).

The statistics NSE, $R^{2}$, PBIAS, and RSR are defined as:

$$
\begin{gathered}
N S E=1-\left[\frac{\sum_{i=1}^{n}\left(Q_{o b s, i}-Q_{s i m, i}\right)^{2}}{\sum_{i=1}^{n}\left(Q_{o b s, i}-\bar{Q}_{o b s, i}\right)^{2}}\right], \\
R^{2}=\frac{\left[\sum_{i=0}^{n}\left(Q_{o b s, i}-\bar{Q}_{o b s, i}\right)\left(Q_{s i m, i}-\bar{Q}_{s i m, i}\right)\right]^{2}}{\left[\sum_{i=0}^{n}\left(Q_{o b s, i}-\bar{Q}_{o b s, i}\right)^{2}\right]\left[\sum_{i=0}^{n}\left(Q_{s i m, i}-\bar{Q}_{s i m, i}\right)^{2}\right]} \\
P B I A S=\left[\frac{\sum_{i=1}^{n}\left(Q_{o b s, i}-Q_{s i m, i}\right)}{\sum_{i=1}^{n}\left(Q_{o b s, i}\right)}\right] * 100
\end{gathered}
$$

where

$$
R S R=\frac{R M S E}{S T D E V_{o b s}}=\frac{\left[\sqrt{\sum_{i=0}^{n}\left(Q_{o b s, i}-Q_{s i m, i}\right)^{2}}\right]}{\left[\sqrt{\sum_{i=0}^{n}\left(Q_{o b s, i}-\bar{Q}_{o b s, i}\right)^{2}}\right]}
$$

$Q_{o b s, i} \quad$ is the $i$ th measurement for basin streamflow,

$Q_{\text {sim }, i} \quad$ is the $i$ th simulated basin streamflow,

$\bar{Q}_{o b s, i} \quad$ is the mean of the measured basin streamflow,

$\bar{Q}_{s i m, i} \quad$ is the mean of the simulated basin streamflow,

RMSE is the root mean square error,

$S T D E V_{\text {obs }}$ is the standard deviation of the observations, and

$n \quad$ is the total number of measurements.

The PRMS models of nine river basins in eastern Iowa were evaluated at 79 calibration and 14 validation gaged sites (fig. 2; table 3). The NSE, $R^{2}$, PBIAS, and RSR daily values for the period used for calibration are listed for each of these sites (table 3). Based on statistical results, the nine eastern Iowa river basin PRMS models are a good fit for daily streamflow estimation at most sites because PBIAS and RSR ratings range from very good to good, and NSE and $R^{2}$ ratings are satisfactory (table 3 ). Some headwater sites show unsatisfactory ratings. Explanation of the statistical results by river basin is provided in "Simulation of Daily Streamflow for Nine River Basins in Eastern Iowa Using the Precipitation-Runoff Modeling System." 


\section{Simulation of Daily Streamflow for Nine River Basins in Eastern lowa Using the Precipitation-Runoff Modeling System}

The estimates of PRMS models of nine river basins in eastern Iowa for daily streamflow at USGS streamflow-gaging stations varied in accuracy when compared to measured daily streamflow data. Models were satisfactory at estimating daily streamflow at USGS streamflow-gaging stations based on statistical results; however, at some gaged sites, the models were below a satisfactory level. Results from the nine eastern Iowa River Basin models are presented below.

The Upper Iowa River Basin PRMS model meets the criteria for satisfactory fit or better for streamflow estimation at all streamflow-gaging stations (table 3 ). A comparison of simulated and measured streamflow at the streamflow-gaging station nearest to the outlet, station 05388250 , shows that for the calibration period (October 1, 2002, through September, 30,2012 ) model output estimates peak timing and volumes well, but either overestimates or underestimates some peak flow volumes (fig. 5).

The Yellow River Basin PRMS model also meets the criteria for satisfactory fit or better for streamflow estimation at all streamflow-gaging stations (table 3 ). A comparison of simulated and measured streamflow at the streamflow-gaging station nearest to the outlet, station 0589000 , shows that for the calibration period (October 1, 2004, through September, $30,2012)$ model output estimates peak timing and volumes well (fig. 5). Peak flow events that happen during the winter months (January, February, and March) are underestimated possibly because of the effects of frozen ground, which are not captured in the version of the model used for this study, the underestimation of rainfall in a rain-snow event, or underestimation of snow-melt runoff. The model also underestimates the record peak flows during 2007 and 2008. These two exceptions and minor base flow discrepancies could be improved upon with more extensive and informed calibration.

The Turkey River Basin PRMS model meets the criteria for satisfactory fit or better for streamflow estimation in all streamflow-gaging stations except at stations 05411600 and 05412340 (table 3). A comparison of simulated and measured streamflow at the streamflow-gaging station nearest to the outlet, station 05412500 , shows that for the calibration period (October 1, 2002, through September, 30, 2012) model output estimates peak timing and volumes well; however, peak flow volumes tend to be underestimated (fig. 5). As with the Yellow River Basin model, the Turkey River Basin model also underestimates peak flow events that happen during the winter months (January, February, and March).

The Maquoketa River Basin PRMS model exceeds the minimum criteria for satisfactory fit or for streamflow estimation in all streamflow-gaging stations except at station 05416900. A comparison of simulated and measured streamflow at the streamflow-gaging station nearest to the outlet, station 05418500 , shows that for the calibration period (October 1, 2002, through September, 30, 2012) model output estimates peak timing and volumes well; however, peak flow volumes during lower flows tend to be overestimated, whereas peak flow volumes during higher flows tend to be underestimated. (table 3; fig. 5).

The Wapsipinicon River Basin PRMS model meets the criteria for satisfactory fit or better for streamflow estimation in all streamflow-gaging stations except at station 05420560. A comparison of simulated and measured streamflow at the streamflow-gaging station nearest to the outlet, station 05422000 , indicates that for the calibration period (October 1, 2002, through September, 30, 2012) model output estimates timing of peak flows well; however, peak flow volumes during lower flows tend to be overestimated, whereas peak flow volumes during higher flows tend to be underestimated (table 3; fig. 5).

The Iowa River Basin PRMS model also exceeds the minimum criteria for satisfactory fit or for streamflow estimation in all but 9 of the 32 streamflow-gaging stations (table 3 ). A comparison of simulated and measured streamflow at the streamflow-gaging stations 05453100 and 05465000 indicates that for the calibration period (October 1, 2002, through September, 30, 2012) model output estimates peak flow timing well (table 3; fig. 5). Peak flow volumes are generally underestimated.

The Skunk River Basin PRMS model also meets the criteria for satisfactory fit or better for streamflow estimation in all streamflow-gaging stations (table 3 ). A comparison of simulated and measured streamflow at the streamflow-gaging station nearest to the outlet, station 05474000 , indicates that for the calibration period (October 1, 2002, through September, 30, 2012) model output estimates peak timing and volumes well; however, peak flow volumes during lower flows tend to be overestimated, whereas peak flow volumes during higher flows tend to be underestimated (table 3; fig. 5).

The Des Moines River Basin PRMS model exceeds the minimum criteria for satisfactory fit or for streamflow estimation in all but 9 of the 29 streamflow-gaging stations (table 3 ). A comparison of simulated and measured streamflow at station 05484500 on the Raccoon River indicates that for the calibration period (October 1, 2002 through September, 30, 2012) model output estimates peak flow timing and volumes well, however peak flow volumes are generally overestimated. A comparison of simulated and measured streamflow at station 05481300 on the Des Moines River shows that for the calibration period (October 1, 2002, through September, 30, 2012) model output estimates peak flow timing and volumes well; however, peak flow volumes during lower flows tend to be overestimated, whereas peak flow volumes during higher flows tend to be underestimated (table 3; fig. 5).

The Fox River Basin PRMS model meets the criteria for satisfactory fit or better for streamflow estimation at one of the two streamflow-gaging stations, the streamflow-gaging station nearest to the outlet, station 05495000 . For the calibration 

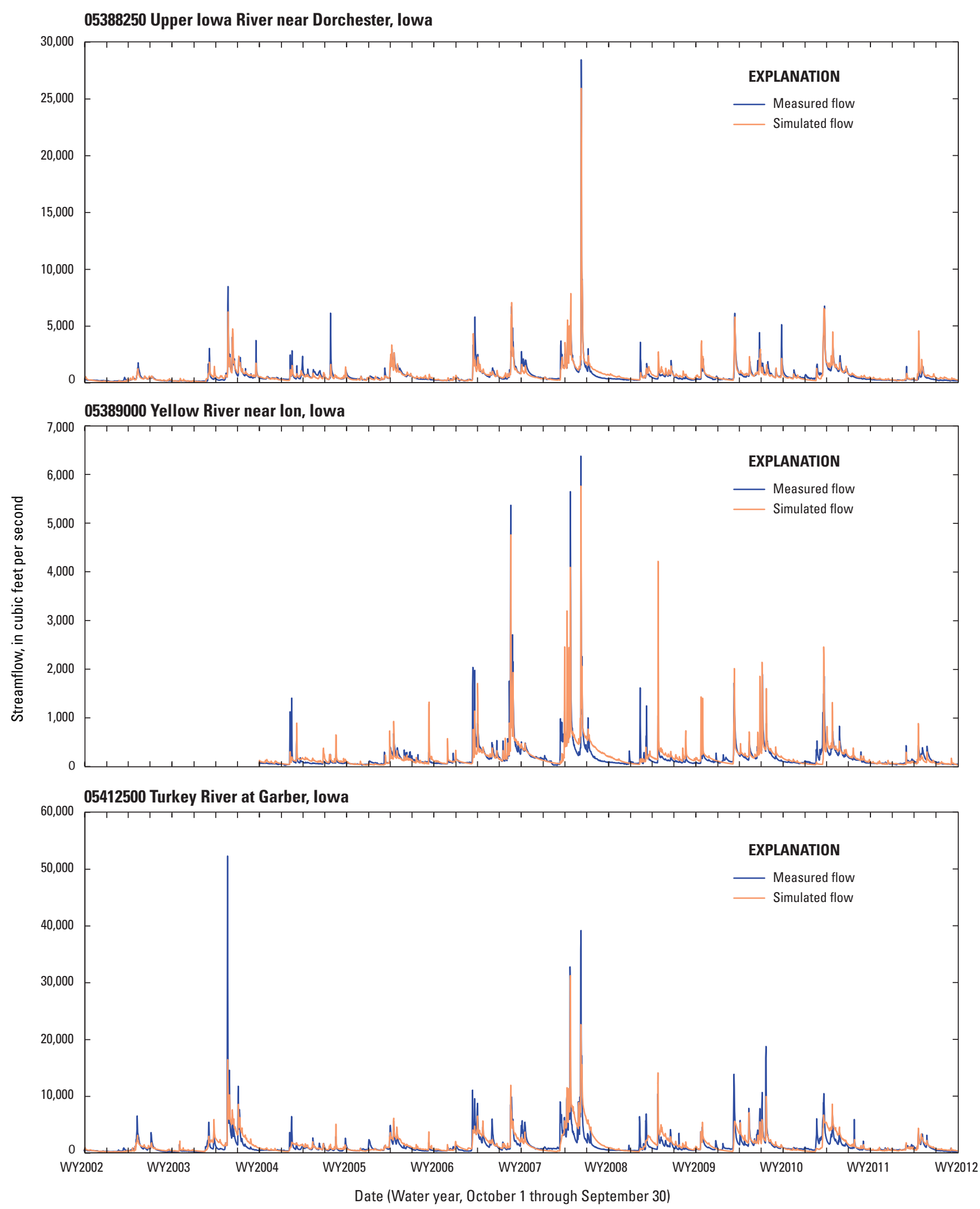

Figure 5. A comparison of measured and simulated flow (October 1, 2002, through September 30, 2012) at selected U.S. Geological Survey streamflow-gaging stations used in calibrating Precipitation-Runoff Modeling System models of nine river basins in eastern lowa, water years (WYs) 2002-12. 
05418500 Maquoketa River near Maquoketa, lowa

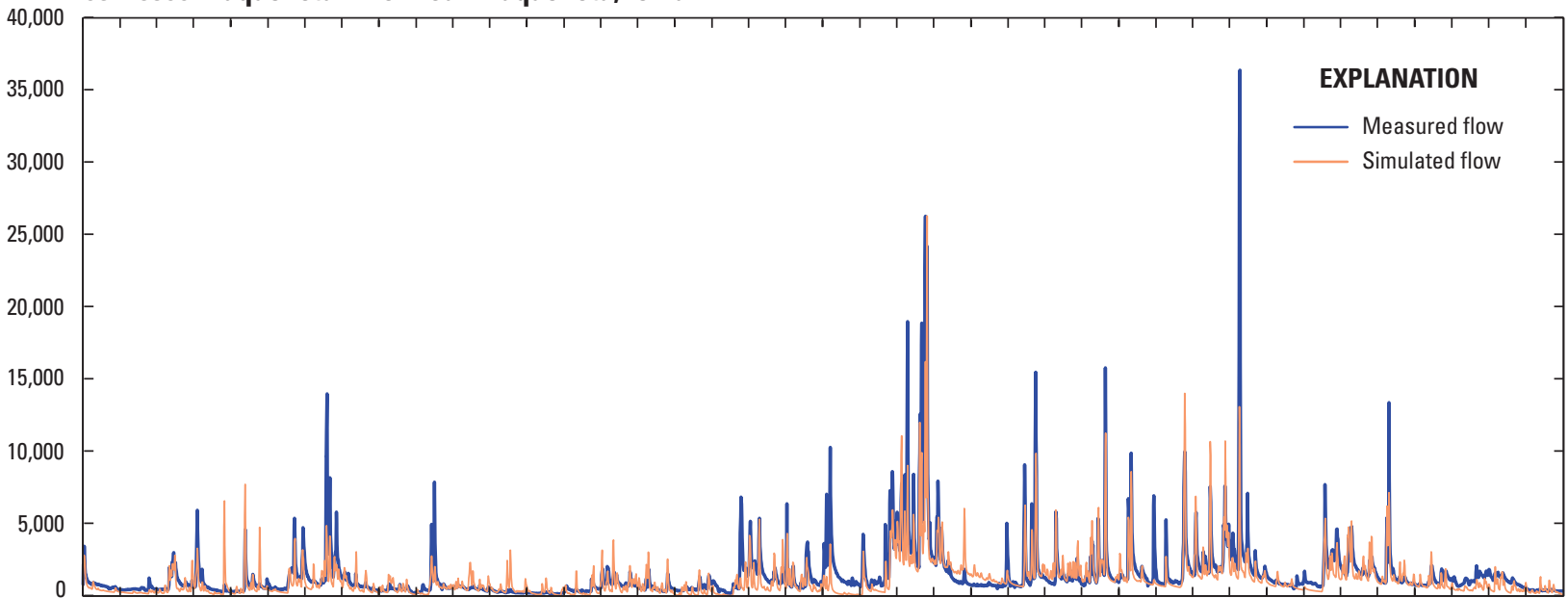

05422000 Wapsipinicon River near De Witt, lowa

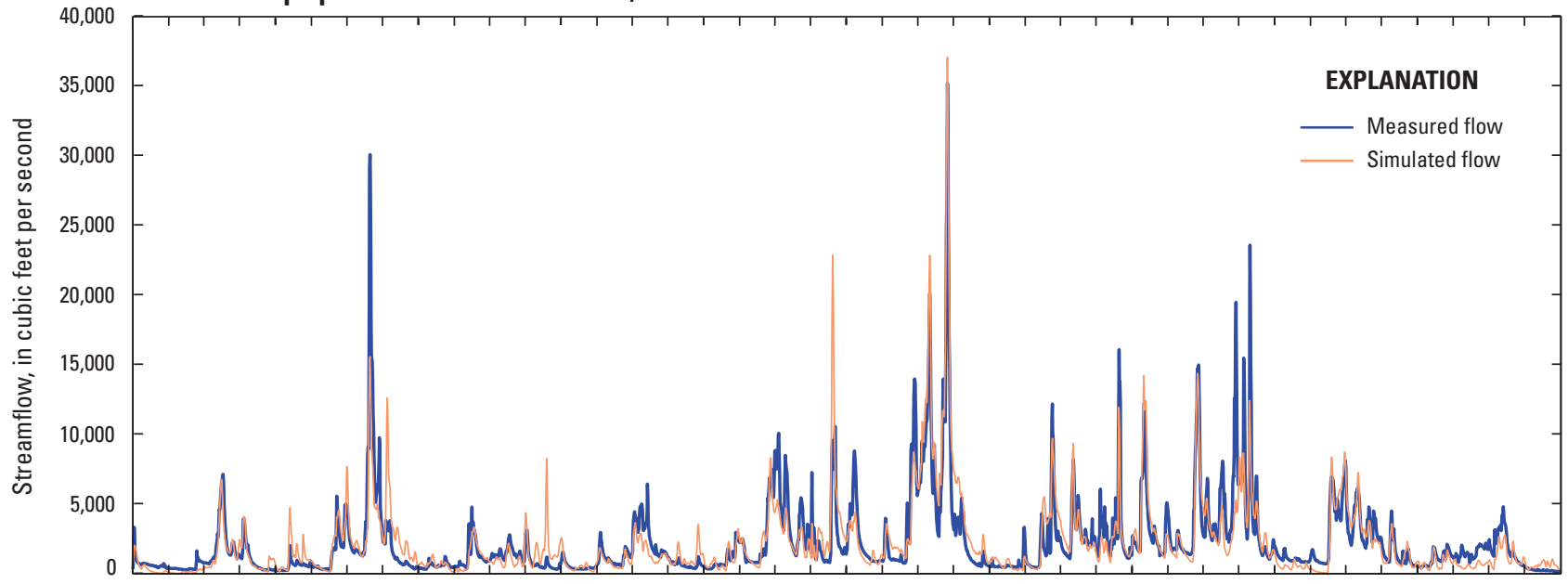

05453100 lowa River at Marengo, lowa

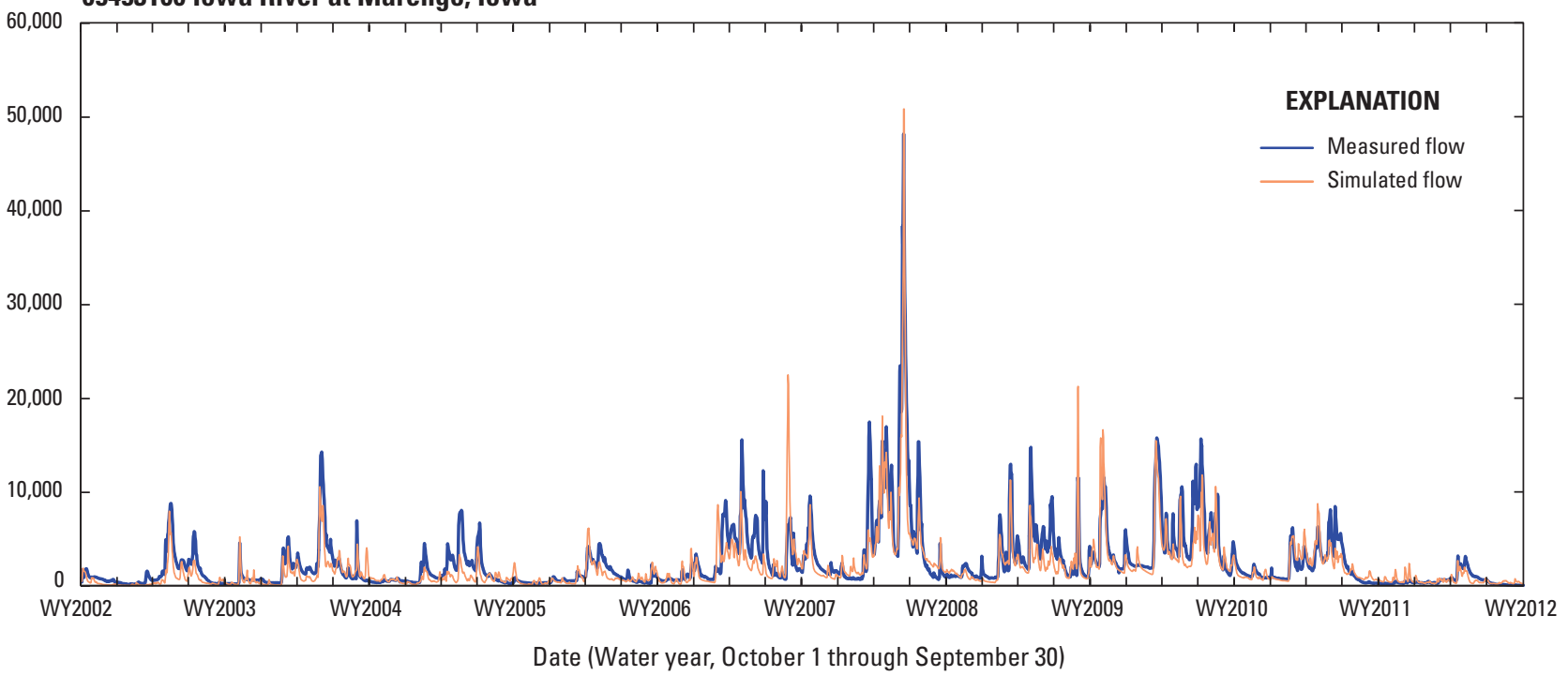

Figure 5. A comparison of measured and simulated flow (October 1, 2002, through September 30, 2012) at selected U.S. Geological Survey streamflow-gaging stations used in calibrating Precipitation-Runoff Modeling System models of nine river basins in eastern lowa, water years (WYs) 2002-12.-Continued 
05465000 Cedar River near Conesville, lowa
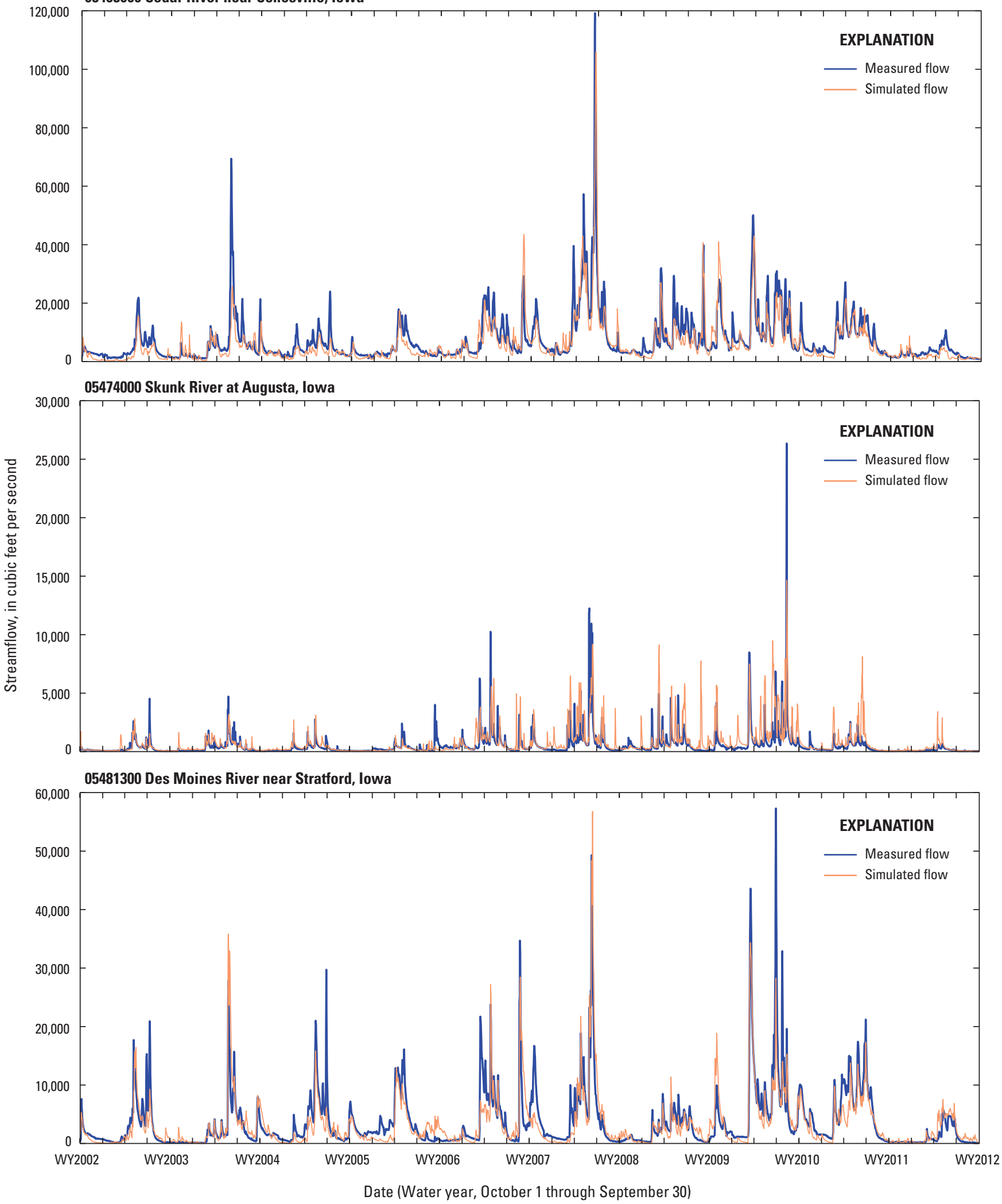

Figure 5. A comparison of measured and simulated flow (October 1, 2002, through September 30, 2012) at selected U.S. Geological Survey streamflow-gaging stations used in calibrating Precipitation-Runoff Modeling System models of nine river basins in eastern lowa, water years (WYs) 2002-12.-Continued 
05484500 Racoon River at Van Meter, lowa

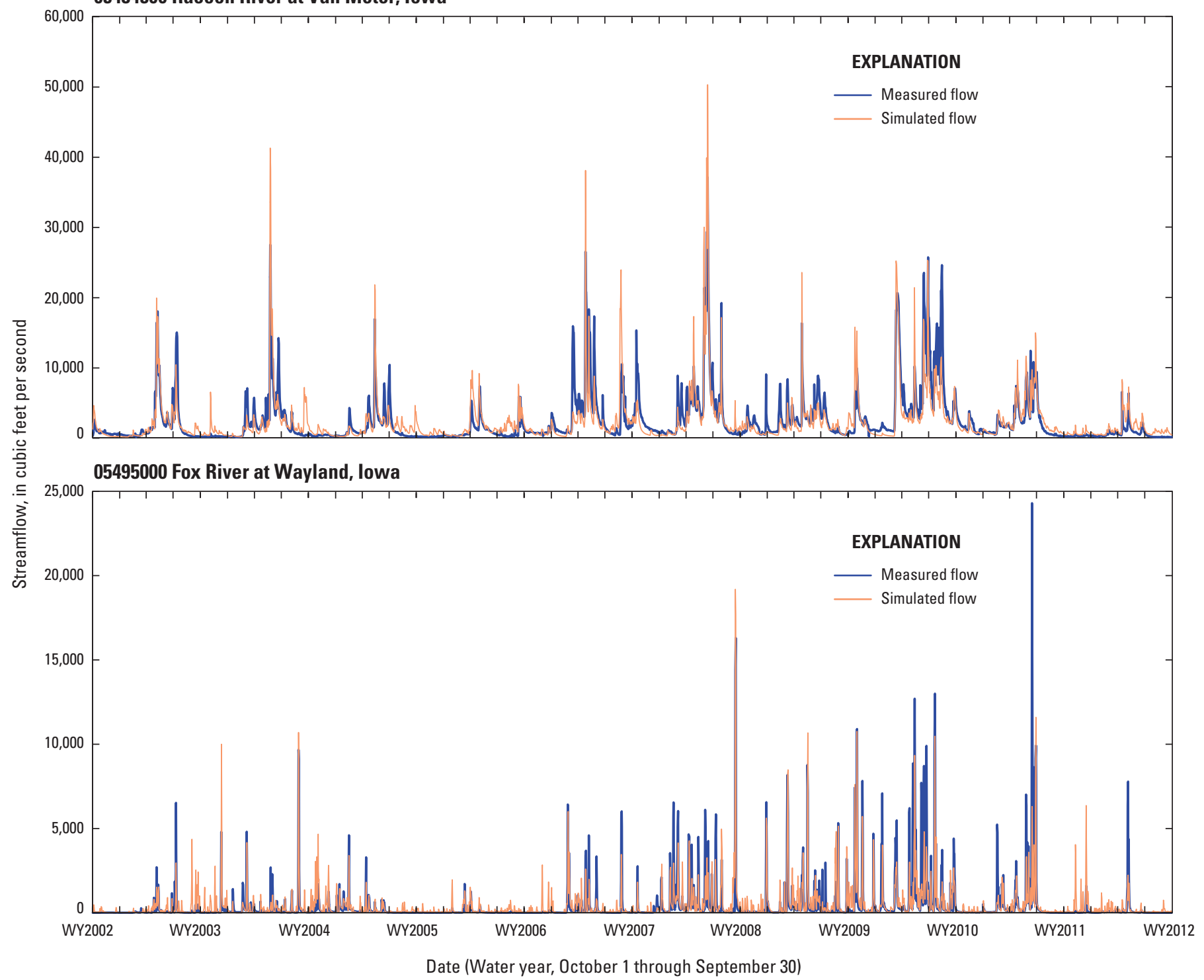

Figure 5. A comparison of measured and simulated flow (0ctober 1, 2002, through September 30, 2012) at selected U.S. Geological Survey streamflow-gaging stations used in calibrating Precipitation-Runoff Modeling System models of nine river basins in eastern lowa, water years (WYs) 2002-12.-Continued 
period (October 1, 2002, through September, 30, 2012), the model output estimates peak flow timing well, but tends to underestimate peak flow volumes, and overestimate and poorly characterize base flow volumes (table 3 ; fig. 5).

Overall, the PRMS models of nine river basins in eastern Iowa constructed for this investigation satisfactorily estimate daily streamflow at 57 of the 79 calibration and 13 of the 14 validation gaged sites as indicated by the NSE, $R^{2}$, PBIAS, and RSR values presented in table 3 . In general, gaged sites in headwater subbasins with small drainage areas and streamflows tended to have less accuracy than the main-stem gaged sites with larger drainage areas and streamflows. The graphs of measured and simulated values at selected USGS streamflowgaging stations within the basins show that the models indicate that unsatisfactory performance may be attributed to several factors: (1) low flow, no flow, and flashy flow conditions in headwater subbasins having a small drainage area; (2) poor representation of the groundwater and storage components of flow within a basin; (3) lack of accounting for basin withdrawals and water use; and (4) the availability and accuracy of meteorological input data. In addition, streamflow is simulated at a daily time step, so shorter-duration, flashy streamflow events are not well represented. A more robust subdaily modeling routine may be necessary at the smaller headwater subbasins to accurately reflect flashy, subdaily climatic events. Further refinement and calibration with more detailed information on groundwater and subsurface storage, water use, and local precipitation and temperature would better guide the proper modeling of low and peak flows and improve model performance.

As indicated in the statistical results at validation gaged sites (which evaluate the accuracy of the model at potential ungaged sites), calibrated models can provide satisfactory streamflow estimates throughout the nine river basins in eastern Iowa, at a model HRU and stream segment scale (table 3). The PRMS models provide a consistent and documented method for streamflow estimation at locations within the basin that may not have available USGS streamflow-gaging station information.

\section{Model Limitations}

The PRMS model uses parameters generated by the GIS Weasel that are dependent upon soil and land cover input datasets (see "Delineation and Parameterization of Spatial Features"). These datasets are dated, have variable degrees of resolution, and may not reflect current land cover or land use conditions in parts of the study area. These inaccuracies may contribute to the overestimation or underestimation of streamflow by the PRMS model.

The PRMS model depends on the use of meteorological datasets to drive the model computations to simulate streamflow. In this study, a network of meteorological stations was used to derive precipitation and temperature model inputs. The spatial distribution of the meteorological stations used to interpolate the spatial distribution of temperature and precipitation within the nine river basins in eastern Iowa is shown in figure 4 . Temperature and precipitation can vary over small distances; this variability may not be captured by meteorological stations; for example, summer thunderstorm activity can produce rapid changes in temperature and a large amount of precipitation in a small area. Summer thunderstorm activity can be missed if there is no meteorological station in the area; thus, the lack of accurate meteorological data over each basin could have contributed to the underestimation or overestimation of daily streamflow. The use of a more robust spatial distribution of climatic data such as Next Generation Radar (NEXRAD), a product of the National Weather Service (NWS), may aid in improving climatic calculations that are the driving forces of the PRMS model (Kalin and Hantush, 2006).

There are several notable limitations in the PRMS models. First, the PRMS models have a daily time step that has all flows and storages expressed as daily mean values. Because of this, error may result because of the daily averaging of near land-surface flows, or when streamflow changes during subdaily time increments (Markstrom and others, 2012). Second, flows and storages are assumed to be homogeneous within each HRU, and some hydrologic complexity and parameter variability within an HRU may be lost. Third, the method of simulating solar radiation values for each HRU does not account for variations in solar activity or changes in atmospheric events. This limitation, however, typically results in only small changes in solar radiation, which have a minimal effect on hydrologic variables and projected basin runoff (Markstrom and others, 2012). Fourth, there are complications in simulations when rain falls on the snowpack in excess of its available pore space. Either the water will runoff the snowpack, in which case it is erroneously considered as snowmelt, or the water will freeze to the snowpack causing the model to later report more snowmelt than snowfall (Markstrom and others, 2012). Both of these cases may complicate interpretation of the model with regard to rain on snowpack events. This study used the Jensen-Haise method (Jensen and others 1970; and Markstrom and others, 2008) to estimate stationary monthly mean values for potential evapotranspiration (PET) at each calibration point for subbasin calibration, which may be a source of uncertainty in the model. Studies (Kingston and others, 2009; and Donohue and others, 2010) show that this uncertainty is reduced because PRMS uses simulated PET, vegetation type, land-use characteristics, soil type, simulated atmospheric conditions, and soil moisture availability to compute actual evapotranspiration (AET), and it is AET that PRMS used in the water balance simulation (Markstrom and others, 2008; and Markstrom and others, 2012). A more detailed discussion of PET uncertainty in the PRMS model is presented in Markstrom and others (2012). 


\section{Summary}

The U.S. Geological Survey (USGS) maintains about 149 real-time streamflow-gaging stations in Iowa where daily mean streamflow information is available. This streamflow information provides the basis for understanding the hydrologic characteristics of basins and, in combination with waterquality information collected at a monthly time step at 75 locations across the State by State and Federal agencies, aids in understanding risks imposed on human and ecosystem health. Because the information collected at these streamflow-gaging stations is site specific, the ability to confidently use these data to infer streamflow information at ungaged sites within a basin for adaptive management and decisions can be limited. Hydrological models are one tool that can be used to overcome this limitation in eastern Iowa. Precipitation-Runoff Modeling System (PRMS) models were constructed in cooperation with the Iowa Department of Natural Resources for nine river basins in eastern Iowa as part of an ongoing research project to examine methods of estimating daily streamflow at gaged and ungaged sites.

The PRMS models were constructed for a total of nine river basins in eastern Iowa that are each a tributary to the Mississippi River: Upper Iowa River Basin, Yellow River Basin, Turkey River Basin, Maquoketa River Basin, Wapsipinicon River Basin, Iowa River Basin, Skunk River Basin, Des Moines River Basin, and Fox River Basin. The construction, calibration, and evaluation of PRMS basin models to simulate daily streamflows and hydrologic components for river basins in eastern Iowa were described. Model performance was assessed to determine the ability of PRMS to estimate streamflow and the suitability for models to serve as part of a suite of methods for estimating daily streamflow at ungaged sites. Model limitations were investigated and described.

The PRMS is a modular, distributed-parameter, physicalprocess basin model developed to evaluate the effects of various combinations of precipitation, climate, and land use on surface-water runoff. The PRMS simulates the hydrologic system with known physical laws and empirical relations derived from basin characteristics. The nine river basins in eastern Iowa were delineated with the GIS Weasel. The GIS Weasel was used to characterize the physical features of each river basin in eastern Iowa into the requisite sets of parameters for input into PRMS.

Precipitation, minimum temperature, and maximum temperature were used in the PRMS models of nine river basins in eastern Iowa as the main climatic drivers. In addition to meteorological inputs, PRMS can also use streamflow-gaging station data in place of simulated streamflow. The USGS streamflow-gaging station data and meteorological datasets for precipitation and temperature were collected using the USGS Downsizer program. The PRMS model was calibrated using the Luca program, which is a multiple-objective, stepwise procedure. Calibration and validation periods used in each basin mostly were October 1, 2002, through September 30, 2012, but differed depending on the period of record available for daily mean streamflow measurements at U.S. Geological Survey streamflow-gaging stations.

Overall, PRMS models of nine river basins in eastern Iowa constructed for this investigation satisfactorily estimate daily streamflow at 57 of the 79 calibration and 13 of the 14 validation gaged sites as indicated by the NSE, $R^{2}$, PBIAS, and RSR values. Unsatisfactory performance may be attributed to several factors: (1) low flow, no flow, and flashy flow conditions in headwater subbasins having a small drainage area; (2) poor representation of the groundwater and storage components of flow within a basin; (3) lack of accounting for basin withdrawals and water use; and (4) the availability and accuracy of meteorological input data. In addition, the version of PRMS used for this study will average a short-duration, flashy streamflow event during a daily time step, whereas a more robust subdaily modeling routine may be necessary at the smaller headwater subbasins to accurately reflect flashy, subdaily climatic events. Further refinement and calibration with more detailed information would better guide the proper modeling of these flow components and improve model performance.

The PRMS models of nine river basins in eastern Iowa can provide satisfactory streamflow estimates at model HRU and stream segment scale. The PRMS models will provide a consistent and documented method for estimating streamflow at locations within the basin that may not have available USGS streamflow-gaging station information.

\section{References Cited}

Christiansen, D.E., 2012, Simulation of daily streamflows at gaged and ungaged locations within the Cedar River Basin, Iowa, using a Precipitation-Runoff Modeling System model: U.S. Geological Survey Scientific Investigations Report 2012-5213, 20 p. [Also available at http://pubs.usgs. gov/sir/2012/5213/.]

Donohue, R.J., McVicar, T.R., and Roderick, M.L., 2010, Assessing the ability of potential evaporation formulations to capture the dynamics in evaporative demand within a changing climate: Journal of Hydrology, v. 386, no. 1-4, p. 186-197. [Also available at http://dx.doi.org/10.1016/j. jhydrol.2010.03.020.]

Duan, Q.Y., Gupta, V.K., and Sorooshian, Soroosh, 1993, Shuffled complex evolution approach for effective and efficient global minimization: Journal of Optimization Theory and Applications, v. 76, no. 3, p. 501-521. [Also available at http://dx.doi.org/10.1007/BF00939380.] 
Dudley, R.W., 2008, Simulation of the quantity, variability, and timing of streamflow in the Dennys River Basin, Maine, by use of a precipitation-runoff watershed model: U.S. Geological Survey Scientific Investigations Report 2008-5100, 44 p. [Also available at http://pubs.usgs.gov/ $\operatorname{sir} / 2008 / 5100 /$.

Gassman, P.W., Reyes, M.R., Green, C.H., and Arnold, J.G., 2007, The soil and water assessment tool-Historical development, applications, and future research directions: Transactions of the American Society of Agricultural and Biological Engineers, v. 50, no. 4, p. 1211-1250. [Also available at http://www.nrcs.usda.gov/Internet/FSE_DOCUMENTS/nrcs143_013639.pdf.]

Goode, D.J., Koerkle, E.H., Hoffman, S.A., Regan, R.S., Hay, L.E., and Markstrom, S.L., 2010, Simulation of runoff and reservoir inflow for use in a flood-analysis model for the Delaware River, Pennsylvania, New Jersey, and New York, 2004-2006: U.S. Geological Survey Open-File Report 2010-1014, 68 p. [Also available at http://pubs.usgs.gov/ of/2010/1014/.]

Gupta, H.V., Sorooshian, Soroosh, and Yapo, P.O., 1999, Status of automatic calibration for hydrologic modelsComparison with multilevel expert calibration: Journal of Hydrologic Engineering, v. 4, no. 2, p. 135-143. [Also available at http://dx.doi.org/10.1061/(ASCE)10840699(1999)4:2(135).]

Haj, A.E., Christiansen, D.E., and Viger, R.J., 2014, The effects of Missouri River mainstem reservoir system operations on 2011 flooding using a Precipitation-Runoff Modeling System model: U.S. Geological Survey Professional Paper 1798-K, 33 p. [Also available at http://dx.doi. org/10.3133/pp1798K.]

Hay, L.E., and Umemoto, Makiko, 2006, Multiple-objective stepwise calibration using Luca: U.S. Geological Survey Open-File Report 2006-1323, 25 p. [Also available at http:// pubs.usgs.gov/of/2006/1323/.]

Homer, Collin, Dewitz, Jon, Fry, Joyce, Coan, Michael, Hossain, Nazmul, Larson, Charles, Herold, Nate, McKerrow, Alexa, VanDriel, J.N., and Wickham, James, 2007, Completion of the 2001 National Land Cover Database for the conterminous United States: Photogrammetric Engineering and Remote Sensing, v. 73, no. 4, p. 337-341. [Also available at http://www.asprs.org/a/publications/pers/2007journal/april/ highlight.pdf.]

Iowa Department of Natural Resources, 2000, Iowa water monitoring plan: Iowa Department of Natural Resources, $12 \mathrm{p}$.
Iowa Department of Natural Resources, 2009, Yellow River State Forest management plan: Conservation and Recreation Division Forestry Bureau, accessed October 1, 2014, at http://www.iowadnr.gov/Portals/idnr/uploads/forestry/ yellowriver-managementplan.pdf.

Jensen, M.E., Robb, D.C.N., and Franzoy, C.E., 1970, Scheduling irrigations using climate-crop-soil data: Proceedings of the American Society of Civil Engineers, Journal of the Irrigation and Drainage Division, v. 96, no. 1, p. 25-38

Kalin, Latif, and Hantush, M.M., 2006, Hydrologic modeling of an eastern Pennsylvania watershed with NEXRAD and rain gauge data: Journal of Hydrologic Engineering, v. 11, no. 6, p. 555-569. [Also available at http://dx.doi. org/10.1061/(ASCE)1084-0699(2006)11:6(555).]

Kingston, D.G., Todd, M.C., Taylor, R.G., Thompson, J.R., and Arnell, N.W., 2009, Uncertainty in the estimation of potential evapotranspiration under climate change: Geophysical Research Letters, v. 36, no. 20, L20403, 6 p. [Also available at http://dx.doi.org/10.1029/2009GL040267.]

LaFontaine, J.H., Hay, L.E., Viger, R.J., Markstrom, S.L., Regan, R.S., Elliott, C.M., and Jones, J.W., 2013, Application of the Precipitation-Runoff Modeling System (PRMS) in the Apalachicola-Chattahoochee-Flint River Basin in the southeastern United States: U.S. Geological Survey Scientific Investigations Report 2013-5162, 118 p., http://pubs. usgs.gov/sir/2013/5162/.

Leavesley, G.H., Lichty, R.W., Troutman, B.M., and Saindon, L.G., 1983, Precipitation-Runoff Modeling System-User's manual: U.S. Geological Survey Water-Resources Investigation Report 83-4238, 207 p. [Also available at http:// pubs.usgs.gov/wri/1983/4238/report.pdf.]

Linhart, S.M., Nania, J.F., Christiansen, D.E., Hutchinson, K.J., Sanders, C.L., Jr., and Archfield, S.A., 2013, Comparison between two statistically based methods, and two physically based models developed to compute daily mean streamflow at ungaged locations in the Cedar River Basin, Iowa: U.S. Geological Survey Scientific Investigations Report 2013-5111, 7 p. [Also available at http://pubs.usgs. gov/sir/2013/5111.]

Markstrom, S.L., Hay, L.E., Ward-Garrison, C.D., Risley, J.C., Battaglin, W.A., Bjerklie, D.M., Chase, K.J., Christiansen, D.E., Dudley, R.W., Hunt, R.J., Koczot, K.M., Mastin, M.C., Regan, R.S., Viger, R.J., Vining, K.C., and Walker, J.F., 2012, Integrated watershed-scale response to climate change for selected basins across the United States: U.S. Geological Survey Scientific Investigations Report 2011-5077, 143 p. [Also available at http://pubs.usgs.gov/ sir/2011/5077/.] 
Markstrom, S.L., Niswonger, R.G., Regan, R.S., Prudic, D.E., and Barlow, P.M., 2008, GSFLOW-Coupled water and surface-water flow model based on the integration of the Precipitation-Runoff Modeling System (PRMS) and the Modular Ground-Water Flow Model (MODFLOW 2005): U.S. Geological Survey Techniques and Methods, book 6, chap. D1, 240 p. [Also available at http://pubs.usgs.gov/tm/ tm6d1/.]

Markstrom, S.L., Regan, R.S., Hay, L.E., Viger, R.J., Webb, R.M.T., Payn, R.A., and LaFontaine, J.H., 2015, PRMS-IV, the precipitation-runoff modeling system, version 4: U.S. Geological Survey Techniques and Methods, book 6, chap. B7, 158 p. [Also available at http://dx.doi.org/10.3133/ tm6B7.]

Moriasi, D.N., Arnold, J.G., Van Liew, M.W., Binger, R.L., Harmel, R.D., and Veith, T.L, 2007, Model evaluation guidelines for systematic quantification of accuracy in watershed simulations: Transactions of the American Society of Agricultural and Biological Engineers, v. 50, no. 3, p. 885-900. [Also available at http://www.ars.usda.gov/ SP2UserFiles/Place/30980000/graphics/MoriasiModelEval. pdf.]

Nash, J.E., and Sutcliffe, J.V., 1970, River flow forecasting through conceptual models part I-A discussion of principles: Journal of Hydrology, v. 10, no. 3, p. 282-290. [Also available at http://dx.doi.org/10.1016/0022-1694(70)902556.]

National Oceanic and Atmospheric Administration, 2014, National Weather Service database, accessed October 1, 2014, at http://www.nws.noaa.gov/om/coop/.

Prior, J.C., 1991, Landforms of Iowa: Iowa City, Iowa, University of Iowa Press, 154 p.

Prior, J.C., Kohrt, C.J., and Quade, D.J., 2009, The landform regions of Iowa, vector digital data: Iowa City, Iowa, Iowa Geological Survey, Iowa Department of Natural Resources, accessed May 12, 2010, at ftp://ftp.igsb.uiowa.edu/gis library/ia_state/geologic/landform/landform_regions.zip.
Singh, Jaswinder, Knapp, H.V., and Demissie, Misganaw, 2004, Hydrologic modeling of the Iroquois River watershed using HSPF and SWAT: Champaign, Ill., Iowa State Water Survey Contract Report 2004-08. [Also available at http:// swat.tamu.edu/media/90101/singh.pdf.]

U.S. Department of Agriculture, 1994, State Soil Geographic (STATSGO) data base-Data use information: Fort Worth, Tex., Soils Conservation Service, National Cartography and GIS Center.

U.S. Department of Agriculture, 2014, 2012 Census of Agriculture- United States summary and state data: Geographical Area Series, v. 1, part 51, AC-12-A-51, U.S. Department of Agriculture, National Agricultural Statistics Service, accessed June 28, 2014, at http://www.agcensus. usda.gov/Publications/2012/Full_Report/Volume_1,_Chapter_1_US/usv1.pdf.

U.S. Geological Survey, 2007, National Elevation Database: U.S. Geological Survey, accessed October 1, 2007, at http:// ned.usgs.gov.

U.S. Geological Survey, 2014, USGS water data for Iowa: U.S. Geological Survey, National Water Information System, accessed October 1, 2014, at http://waterdata.usgs.gov/ ia/nwis/.

Viger, R.J., and Leavesley, G.H., 2007, The GIS Weasel user's manual: U.S. Geological Survey Techniques and Methods, book 6, chap. B4, 201 p. [Also available at http://pubs.usgs. gov/tm/2007/06B04/.]

Ward-Garrison, C.D., Markstrom, S.L., and Hay, L.E., 2009, Downsizer-A graphical user interface-based application for browsing, acquiring, and formatting time-series data for hydrologic modeling: U.S. Geological Survey Open-File Report 2009-1166, 27 p. [Also available at http://pubs.usgs. gov/of/2009/1166/.] 
Publishing support provided by:

Rolla Publishing Service Center

For more information concerning this publication, contact:

Director, USGS lowa Water Science Center

P.O. Box 1230

lowa City, IA 52244

(319) 337-4191

Or visit the lowa Water Science Center Web site at: http://ia.water.usgs.gov/ 


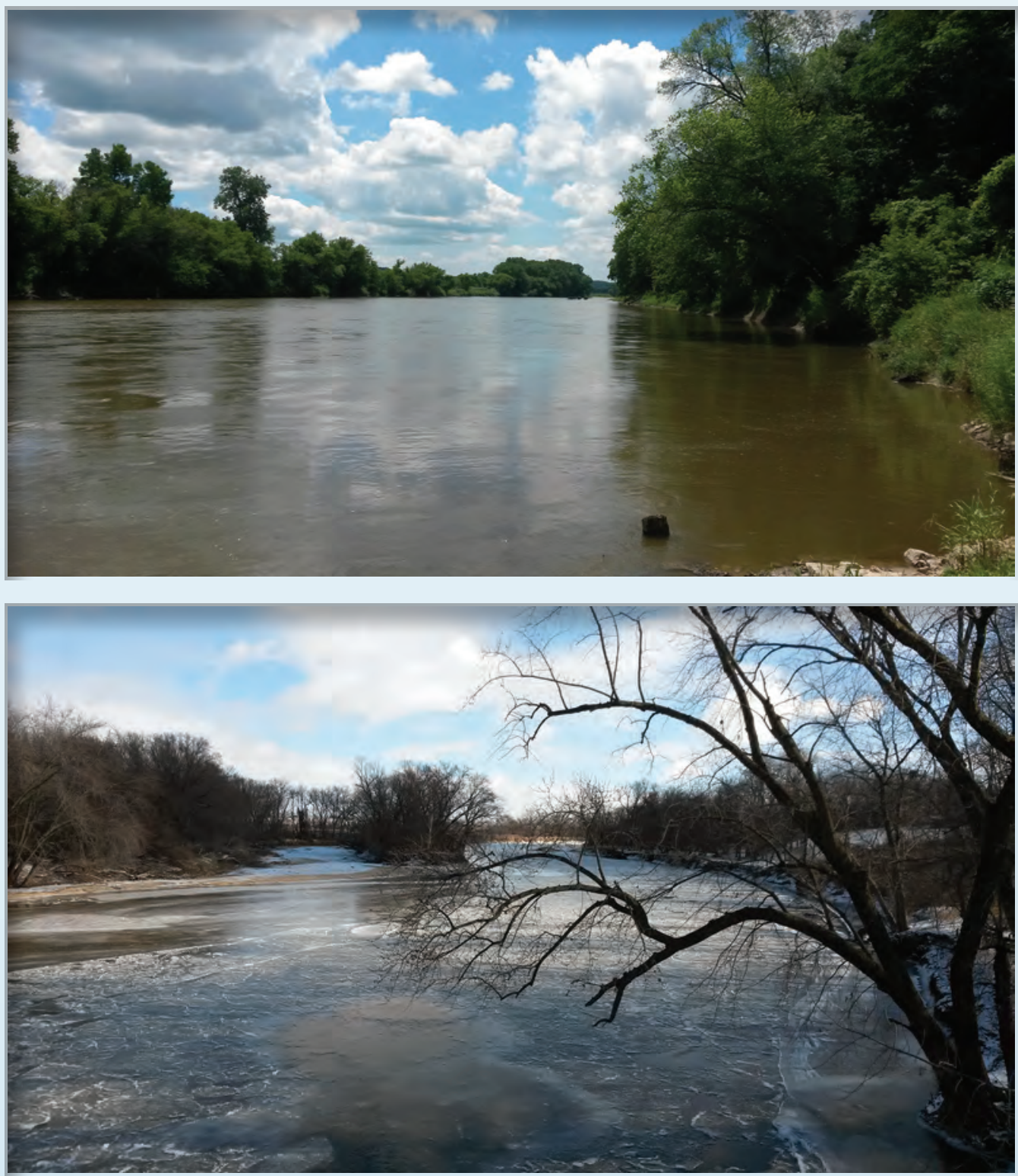

ISSN 2328-0328 (online) 